\title{
Why does COVID-19 disproportionately affect older people?
}

Review

\author{
Amber L. Mueller ${ }^{1}$, Maeve S. McNamara ${ }^{1}$, David A. Sinclair ${ }^{1}$ \\ ${ }^{1}$ Glenn Center for Biology of Aging Research, Blavatnik Institute, Harvard Medical School, Boston, MA 20115, USA
}

Correspondence to: Amber L. Mueller, David A. Sinclair; email: amber mueller@hms.harvard.edu,

david_sinclair@hms.harvard.edu

Keywords: aging, cytokine storm, COVID-19, epigenetic clock, immunity

Received: April 29, $2020 \quad$ Accepted: May 18, $2020 \quad$ Published: May 29, 2020

Copyright: Mueller et al. This is an open-access article distributed under the terms of the Creative Commons Attribution License (CC BY 3.0), which permits unrestricted use, distribution, and reproduction in any medium, provided the original author and source are credited.

\begin{abstract}
The severity and outcome of coronavirus disease 2019 (COVID-19) largely depends on a patient's age. Adults over 65 years of age represent $80 \%$ of hospitalizations and have a 23-fold greater risk of death than those under 65. In the clinic, COVID-19 patients most commonly present with fever, cough and dyspnea, and from there the disease can progress to acute respiratory distress syndrome, lung consolidation, cytokine release syndrome, endotheliitis, coagulopathy, multiple organ failure and death. Comorbidities such as cardiovascular disease, diabetes and obesity increase the chances of fatal disease, but they alone do not explain why age is an independent risk factor. Here, we present the molecular differences between young, middle-aged and older people that may explain why COVID-19 is a mild illness in some but life-threatening in others. We also discuss several biological age clocks that could be used in conjunction with genetic tests to identify both the mechanisms of the disease and individuals most at risk. Finally, based on these mechanisms, we discuss treatments that could increase the survival of older people, not simply by inhibiting the virus, but by restoring patients' ability to clear the infection and effectively regulate immune responses.
\end{abstract}

\section{INTRODUCTION}

Severe Acute Respiratory Syndrome coronavirus 2 (SARS-CoV-2), which is responsible for the worldwide pandemic of coronavirus disease (COVID-19) originated in Wuhan, China, in late 2019 [1]. COVID-19 has so far killed more than 350,000 people, with the majority of deaths (74\%) occurring in people over the age of 65 [2, $3]$. Why the disease is particularly dangerous in older people is not yet known and poorly understood at the molecular level. It is clear, however, that age alone is by far the most significant risk factor for death due to COVID-19 [4, 5]. Even prior to SARS-CoV-2, human coronaviruses and influenza viruses have been known to impact older people disproportionately [6], yet therapeutic strategies to protect this fraction of the population, with the exception of vaccines, have largely failed. The severity of COVID-19 is, of course, strongly associated with comorbidities such as hypertension, diabetes, obesity, cardiovascular disease, and respiratory system diseases [2]. Whether these comorbidities con- tribute specifically to SARS-CoV-2 pathogenesis or whether they are primarily indicators of biological age remains an open question. For example, simple explanations for the impact of age that are based solely on co-morbidities or on a general lack of resilience in aging, for example, fail to explain why the immune system often reacts uncontrollably.

SARS-CoV-2 is transmitted through respiratory droplets or by direct contact. Entering the nose, mouth or eyes, the virus spreads to the back of the nasal passages, where it binds to and enters via the dimerized angiotensin-converting enzyme 2 (ACE2) [7] on the surface of airway epithelial cells [8]. From there, it spreads to the mucous membranes of the throat and bronchial tubes, eventually entering the lungs where it infects type 2 alveolar epithelial cells called pneumocytes. This can lead to acute respiratory distress syndrome (ARDS), characterized by a loss of beneficial lung surfactant and an increase in oxidative stress and inflammation $[9,10]$ (Figure 1). 
Particularly the older people, severe cases of the disease are characterized by acute lung injury and ARDS, the latter of which is typically treated by positive airway pressure with oxygen and pronation or invasive ventilation. This stage is characterized by neutrophilia, lymphocytopenia, lung consolidation, and bilateral nodular and peripheral ground glass opacities on chest $\mathrm{X}$-rays. The ACE2 protein is widely expressed on the surface of both epithelial and microvascular pericytes, that traverse multiple organs, allowing both cell types to be infected by the virus $[11,12]$. The recruitment of immune cells to sites of infection results in widespread inflammation and endothelial dysfunction in the lung, heart, kidney, and liver and brain, with prominent endotheliitis of the submucosal vessels and apoptotic bodies [11].
Even if viral loads decline in the patient,, a type of cytokine release syndrome can rapidly develop, characterized by disseminated intravascular coagulation (DIC), causing liver damage, renal dysfunction, cardiovascular inflammation, coagulopathy and death $[13,14]$. There are very few studies that definitely connect the known mechanisms of aging to the pathogenesis of viruses. In this perspective, we offer potential mechanistic explanations as to why COVID-19 advances in some people and not others, and especially in older patients, including differences in the immune system, glycation, the epigenome, inflammasome activity, and biological age. We also discuss therapies that may improve immunity against viral infection while enhancing the ability of older people to recover from severe COVID-19.

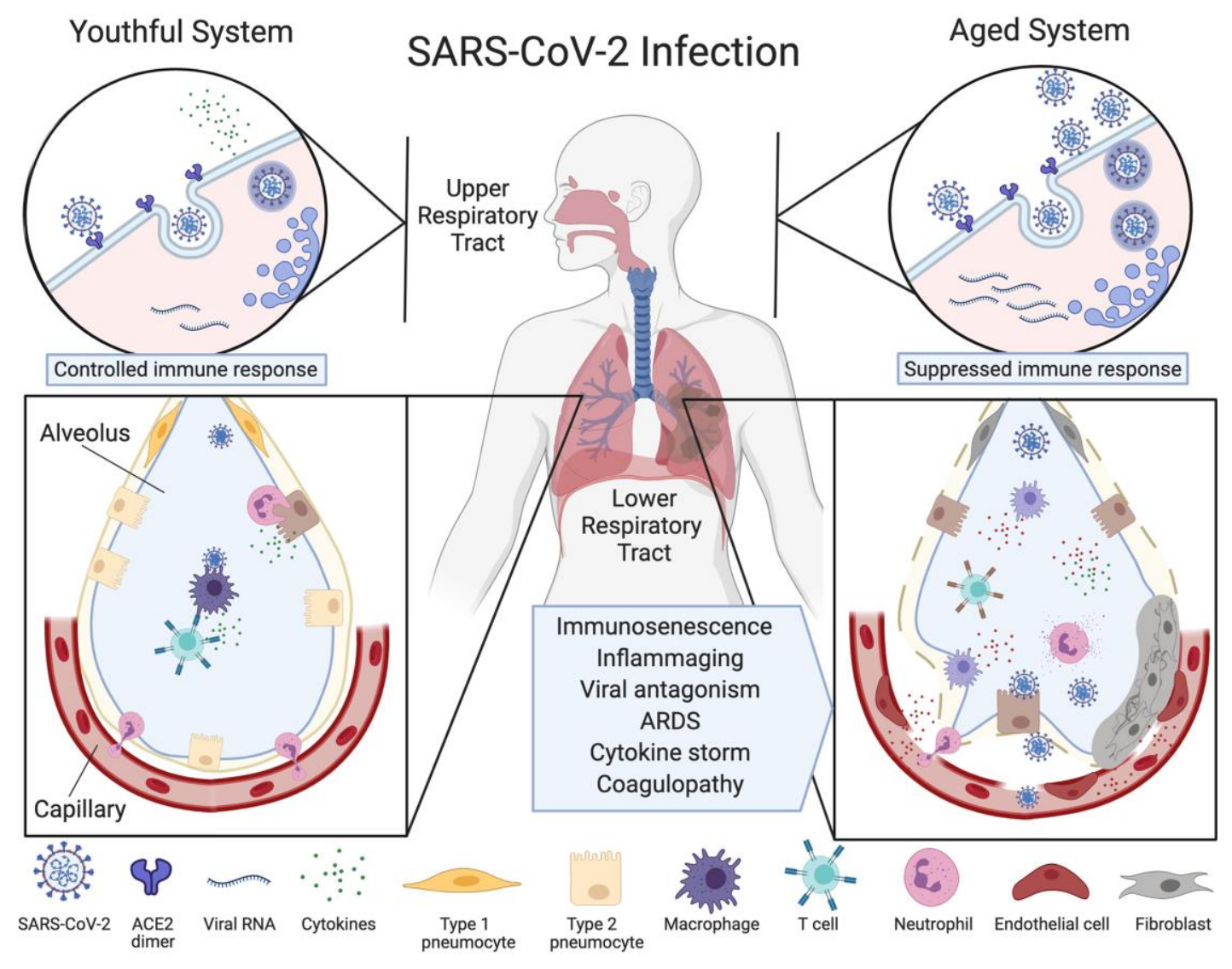

Figure 1. Ineffective clearance of SARS-CoV-2 infection in the aged respiratory system. The SARS-CoV-2 virus binds to ACE2 enzymes on airway epithelial cells in the upper respiratory tract where they are endocytosed and replicated (top left), alerting the immune system. Viruses then travel to the alveoli and infect type 2 pneumocytes which, in the youthful system (lower left), are recognized by alveolar macrophages (AMs) or dendritic cells (not pictured) that release cytokines and present antigens to $\mathrm{T}$ cells and other adaptive immune cells. T cells with the appropriate receptors activate other lymphocytes or directly kill infected cells, preventing the spread of the virus. Neutrophils migrate to the sites of infection to clear infected cell debris. In the aged system (top right), viral alert signals are initially slow, resulting in greater viral replication. Defective macrophages and T cells with a limited repertoire of receptors are less effective (lower right). More cells are infected, inducing high levels of inflammatory cytokine signaling. The endothelial cell lining of the capillary becomes inflamed, fibroblasts are activated, and SARS-CoV-2 viral components and cytokines enter the bloodstream. Fluid fills the alveolus, reducing lung capacity and the virus infects microvascular pericytes in other organs. A cytokine storm initiates microvasculature clotting, causing severe hypoxia, coagulopathy and organ failure. Created with BioRender. 


\section{The aging immune system}

The ability to control viral load is one of the best prognostics of whether a patient will have mild or severe COVID-19 symptoms [15]. For the immune system to effectively suppress then eliminate SARSCoV-2, it must perform four main tasks: (1) recognize, (2) alert, (3) destroy and (4) clear. Each of these mechanisms are known to be dysfunctional and increasingly heterogeneous in older people $[16,17]$. But which tasks are most relevant to COVID-19 progression in older people is not yet clear [18].

During aging, the immune system changes in two major ways. One is a gradual decline in immune function called immunosenescence, which hampers pathogen recognition, alert signaling and clearance. This is not to be confused with cellular senescence, an aging-related phenomenon whereby old or dysfunctional cells arrest their cell cycle and can become epigenetically locked into a pro-inflammatory state in which they secrete cytokines and chemokines. The other classic immune system change during aging is a chronic increase in systemic inflammation called inflammaging, which arises from an overactive, yet ineffective alert system [19].

An abundance of recent data describing the pathology and molecular changes in COVID-19 patients points to both immunosenescence and inflammaging as major drivers of the high mortality rates in older patients. Within immunosenescence, there are defects in both the innate and adaptive immune systems. Innate immunosenescence is characterized by ineffective pathogen recognition and macrophage activation, and a reduction in natural killer (NK) cell cytotoxicity, whereas adaptive immunosenescence is characterized by thymic atrophy and accumulation of anergic memory lymphocytes. In both cases, these age-related changes are thought to be due to pathogenic, genetic, and lifestyle factors that affect the cells' epigenetic status and the diversity of immune cells.

\section{The aging innate immune system}

The innate immune system is the body's first line of defense against coronaviruses. Sentinel cells, such as macrophages and dendritic cells, recognize structurally conserved viral proteins via single-pass membrane-spanning receptors called Toll-like receptors (TLRs) expressed on their cell surfaces. Defects in TLR function in innate immune cells are known to increase the severity of pneumonia in mice, especially in the context of aging and chronic inflammaging [20]. Alveolar macrophages (AMs) are mononuclear phagocytes that surveil the lungs for dust, allergens and the remnants of pathogens. When their TLRs detect an invader, AMs respond by producing type I interferons, which attract immune cells to the site of infection and present antigens to lymphocytes [21, 22]. Although AMs increase in number during aging, their plasticity to convert between pro- and anti-inflammatory states is greatly reduced [23], exemplified by a weak cytokine response after TLR activation [24] (Figure 1).

The inability of AMs in older individuals to recognize viral particles and convert to a pro-inflammatory state likely accelerates COVID-19 in its early stages, whereas in its advanced stages, AMs are likely to be responsible for the excessive lung damage. A recent study comparing immune cell composition of bronchoalveolar lavage fluid from moderate and severe COVID-19 patients showed in severe cases, macrophages were phenotypically more proinflammatory, expressing higher levels of CCR1 and CXCR2 that recruit other innate immune cells, compared to macrophages from moderate COVID-19 cases that expressed more $\mathrm{T}$-cell attracting chemokines [25]. Prolonged monocyte activation is a well-known cause of severe lung injury in rhesus monkeys [26] and in cases of SARS (caused by SARS-CoV-1), higher numbers of pulmonary neutrophils and macrophages correlated with the development of ARDS and greater lung damage [27]. A decline in neutrophil activity might also be partly responsible because, during aging, these cells progressively lose their ability to migrate to sites of infection and kill infected cells [28, 29]. NK cells, a major component in innate immunity with potent cytotoxic activity, are an unlikely cause of COVID-19 severity. Their numbers are relatively stable during aging [30] and in a mouse model of SARS, they were not necessary for normal viral clearance [31]. To discern which of these cell types play the most destructive roles, more detailed analyses of COVID19 patient autopsy tissue will be needed.

Additionally, the production and diversity of mucins, protective glycoproteins found in mucosal barriers throughout the body, also change in aging [32, 33], although their role in immunity against coronaviruses in humans is understudied.

\section{The aging adaptive immune system}

Immunosenescence of the adaptive immune system is also a likely factor that determines whether a patient progresses to severe COVID-19 (Figure 2). Situated just above the heart, the thymus - a primary lymphoid organ and the site of $\mathrm{T}$ cell development and maturation of early thymic progenitors from the bone marrow - is one 
of the first tissues to experience aging. By age 65 , the thymus is on average $\sim 40 \%$ its original size [34], coincident with activation of the inflammasome component NLRP3 and Caspase-1, a pro-apoptotic protease [35, 36]. A build-up of intrathymic adipocytes further reduces thymic cellularity and deteriorates the thymic microenvironment. Thymic atrophy also contributes to a reduction of naïve $T$ cells and an accumulation of memory lymphocytes, resulting in defective immunosurveillance and an exhaustion of $\mathrm{B}$ cells, cytotoxic $\mathrm{T}$ cells, and helper $\mathrm{T}$ cells [37]. Other common effects of aging on the adaptive immune system include a decline in the production of fresh naïve $\mathrm{T}$ cells, a less expansive $\mathrm{T}$ cell receptor (TCR) repertoire, $\mathrm{T}$ cell metabolic dysfunction, and weaker activation of $\mathrm{T}$ cells $[38,39]$. Clonal populations of
$\mathrm{CD}^{+} \mathrm{T}$ cells expand during aging, limiting their diversity, whereas $\mathrm{CD}^{+} \mathrm{T}$ cells retain fairly diverse TCRs [40] and, instead, suffer activation deficits [39].

Interestingly, one study found that supercentenarians defined as adults over 110 years old - tend to have an unusual population of cytotoxic $\mathrm{CD}^{+}{ }^{+} \mathrm{T}$ cells whose activation doesn't decline with age and can take on the effector functions usually performed by $\mathrm{CD} 8^{+} \mathrm{T}$ cells [41]. This $\mathrm{T}$ cell behavior may explain why some older people, even some people over 100, are able to survive COVID-19. Measuring the repertoire and frequency of TCRs in patients from a spectrum of ages and disease severity should be performed to determine if a loss of $\mathrm{T}$ cell diversity is a reason why SARS-CoV-2 viral loads tend to spike in older people but not the young.

\section{COVID-19 Fatality Risk}
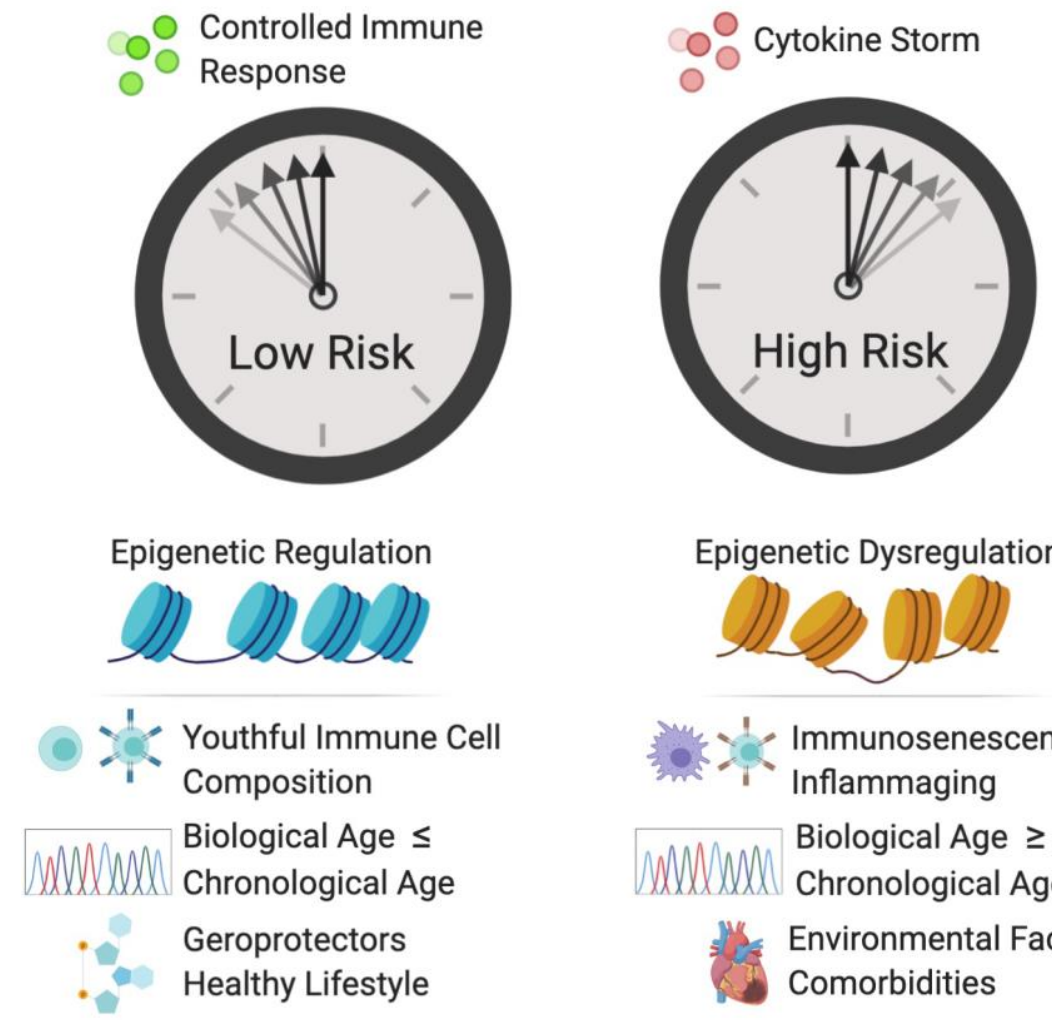

Epigenetic Dysregulation
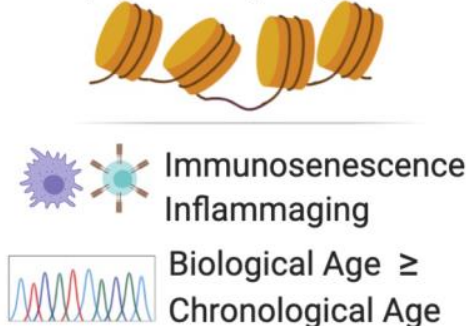

Biological Age $\geq$

Chronological Age

Environmental Factors

Comorbidities

Figure 2. Factors that increase the fatality risk of COVID-19. Epigenetic dysregulation, immune defects, advanced biological age, and other factors increase the risk of cytokine storm and COVID-19 fatality. Tightly controlled activation of the innate immune system is essential for viral recognition and clearance. Cytokine storm is the result of sustained activation of the inflammatory signaling cascade and can result in hypercoagulation in small blood vessels, which leads to tissue damage, DIC and multi-organ failure. Inflammaging and immunosenescence contribute to the development of cytokine storm. D-dimer, a fibrin degradation product and prognostic of disseminated intravascular coagulation (DIC), and elevated levels of the cytokine, IL-6, are associated in the clinic with increased fatality. Epigenetic dysregulation of the immune system and of the renin-angiotensin system (RAS) may increase fatality risk. A variety of biological clocks have been shown to predict human health and longevity more accurately that chronological age. An individual with a biological age greater than their chronological age is thought to be undergoing accelerated aging, which may increase the risk of COVID-19 fatality. Individuals with comorbidities such as cardiovascular disease, diabetes, obesity and COPD, are at greater risk for COVID-19 fatality. Conversely, individuals who live healthy lifestyles and consume geroprotectors such as metformin, resveratrol and NAD+ boosters may have a decreased risk of fatality. Created with BioRender. 
Not only does the repertoire of $\mathrm{T}$ cells decline in aging, so do their numbers. Those over 60 years old increasingly have low $\mathrm{T}$ cell numbers, a condition known as lymphopenia [42]. Because $\mathrm{T}$ cells express very low levels of ACE2, the lymphopenia in COVID19 patients is unlikely to be caused by direct SARSCoV-2 infection [43], as in the case for HIV. One proposed cause of the $\mathrm{T}$ cell paucity is an exhaustion of the immune system driven by repeated exposures to viruses over one's lifetime [42, 44, 45]. This hypothesis is based on several studies that tracked the morbidity and mortality of people over 60 who had been chronically infected with human cytomegalovirus (CMV) [46, 47]. Cycles of CMV reemergence were associated with vast immune system remodeling, including a pronounced exhaustion of $\mathrm{CD}^{+} \mathrm{T}$ cells that was more predictive of all-cause mortality than chronological age. Other studies indicate that $\mathrm{T}$ cell depletion is due to the cumulative exposure to many different pathogens and lifestyle factors, not CMV alone $[46,48]$. At the chromosomal level, a major cause of immune exhaustion is telomere shortening in viralspecific memory $\mathrm{CD}^{+} \mathrm{T}$ cells, which induces cellular senescence, a state of cell cycle arrest and hyperinflammation that prevents expansion upon re-infection [49]. The fact that in the most severe COVID-19 cases bronchoalveolar $\mathrm{CD} 8^{+} \mathrm{T}$ cells appear to have reduced expansion capability [25] and peripheral blood $\mathrm{T}$ cells express high levels of the immune-exhaustion marker PD-1 [42] make this theory plausible.

B cells - adaptive immune cells which produce antibodies in response to coronavirus antigens [21] - are also less diverse and less responsive in aging [50, 51]. While total B cells numbers do not decrease in aging, memory B cells accumulate and naïve B cells are depleted, which may lead to loss of diversity of the B cell repertoire, although this has not yet been definitively demonstrated in humans [51]. Changes in IgG glycosylation patterns, however, have been shown to strongly associate with age and inflammation, and predict age-associated disease development [52]. In particular, IgG N-glycans appear to be the most predictive of biological aging, however B-cell intrinsic and extrinsic regulation of glycosylation in aging require further study.

Due to a lack of sun exposure and decreased production of vitamin $\mathrm{D}$, about half of all older people have a deficiency in this vitamin [53], which reduces the efficacy of both adaptive and innate immune responses and increases the risk of infection [54]. Vitamin D levels in older people are correlated with preserved features of immunity such as the $\mathrm{CD} 4^{+} / \mathrm{CD}^{+}$ratio and lower levels of pro-inflammatory cytokines after stimulus $[54,55]$. Although not all studies see a benefit of vitamin D supplementation on the risk or duration of lower respiratory infections [56], the majority have, especially in those with an antibody deficiency or increased susceptibility to respiratory tract infections [57, 58]. A recent meta-analysis of 25 randomized, placebo-controlled trials concluded that vitamin D supplementation prevented about 20\% of acute respiratory infections [59]. As such, some health professionals have recommended vitamin $\mathrm{D}$ supplementation for older people in general and especially for aged-care residents and critically ill patients as a strategy for improving chances of COVID19 survival.

\section{Increased inflammation and cytokine storms in the aged}

During the course of COVID-19, older patients can reduce their viral titers, only to rapidly descend into a state of shock involving hyperactivation of the immune system and hypercoagulation in small blood vessels [42, 60]. This rapid and uncontrolled inflammatory signaling cascade typically occurs in the later stages of infection. Known as a "cytokine storm," it exacerbates the dyspnea and hypoxemia, and triggers inflammation in major tissues such as the lungs, kidneys, heart, liver and brain. Cytokine storm syndrome is defined as life-threatening organ dysfunction caused by a maladaptive host response to an infectious trigger [61]. The resulting vascular inflammation is emerging as the cause of complementassociated microvascular injury and thrombosis in severe COVID-19 cases [62]. The initial trigger for cytokine storm is not yet known but it likely involves the immune system's detection of a large quantity of viral antigens released by dying cells. Why older people are particularly prone to cytokine storms is also unclear.

The cytokine profiles of late-stage COVID-19 patients are similar to patients with secondary haemophagocytic lymphohistocytosis, a type of cytokine storm that can be triggered by systemic viral infection, including increased levels of interleukin (IL)-2, IL-6, IL-7, C-reactive protein (CRP), granulocyte-colony stimulating factor (GCSF), interferon- $\gamma$ inducible protein 10 (IP-10), monocyte chemoattractant protein-1 (MCP-1), macrophage inflammatory protein 1- $\alpha$ (MIP1- $\alpha$ ) and tumor necrosis factor- $\alpha(\mathrm{TNF}-\alpha)[45,63,64]$.

Even more predictive of death than serum cytokine profiles is an increase in the fibrin degradation product D-dimer, released from blood clots in the microvasculature, and a prognostic for DIC [9]. As such, Ddimer is now widely regarded as a key indicator of the severity of late-stage COVID-19. D-dimer levels naturally increase with age, most likely reflecting a 
higher basal level of vascular inflammation [65], which could predispose patients to severe COVID-19. It would, therefore, be informative to know if precytokine storm levels of D-dimer levels could predict who is likely to develop a cytokine storm.

In cytokine storms, high levels of IL-6 cause vascular endothelial cells to secrete fibrin, which causes DIC. In the lung, this may underlie the hypoxemia seen in patients with seemingly functional lungs. If left untreated, clots leach additional clotting factors from the bloodstream, increasing the risk of bleeding (coagulopathy) and multi-organ failure. Drugs such as tocilizumab (Actemra), which block IL-6 receptor activity, are currently being used in patients in advanced stages [66].

One in two fatal cases of COVID-19 experience a cytokine storm, $82 \%$ of whom are over the age of 60 [67]. Though there may be many simultaneous triggers of the storm, abundant evidence indicates that inflammaging is a major driver, exacerbated by obesity, poor diets and oral health, microbial dysbiosis, and sedentary lifestyles $[68,69]$. For example, in rodents, inflammaging increases the risk of cytokine storm syndrome [70] and, in humans, age correlates with higher basal circulating levels of pro-inflammatory cytokines including IL-6, TNF- $\alpha$, IL-1 $\alpha$ and CRP $[71,72]$.

A central player that could help explain the predisposition to cytokine storms is NLRP3, the major protein component of the inflammasome. During aging, there is a steady increase in the abundance and activity of NLRP3 in immune cells, including AMs of the lung which, upon chronic stimulation, contribute to pulmonary fibrosis [73]. NLRP3 inflammasome activation requires two steps, the first of which is the priming step, induced by TLRs or tumor necrosis factor receptor activation. This leads to the activation of NF$\kappa \mathrm{B}$ and promotes the expression of NLRP3, pro-IL-1 $\beta$, and pro-IL-18. The second step, also called the activation step, is triggered by a range of stimuli that emerge during infections, such as tissue damage, nucleic acids, and invading pathogen proteins [74].

In older individuals, NLRP3 may be poised for hyperactivation by SARS-CoV-2 antigens. NLRP3 activity is under the direct control of sirtuin 2 (SIRT2), a member of the $\mathrm{NAD}^{+}$-dependent sirtuin family of deacetylases (SIRT1-7) [75]. During aging, $\mathrm{NAD}^{+}$levels decline, reducing the activity of the sirtuins [76]. Old mice, especially those deficient in SIRT2, have decreased glucose tolerance and increased insulin resistance [77]. This decline, exacerbated by COVID-19, might promote hyperactivation of NLRP3 and the trigger cytokine storms in COVID-19 patients [14]. Maintaining NAD ${ }^{+}$ levels may therefore alleviate COVID-19 symptoms, a possibility supported by recent data showing that SARS-CoV-2 proteins hyperactivate poly-ADP-ribose polymerases PARP9, $-10,-12$, and -14 and deplete cellular $\mathrm{NAD}^{+}$[78]. Additionally, $\mathrm{NAD}^{+}$precursors lower inflammation in human subjects $[79,80]$.

Mechanisms of infection in other coronaviruses support the hypothesis that NLRP3 activation is a trigger of cytokine storms in the aged. The SARS-CoV-1 ORF3a protein, for example, is a potent activator of pro-IL-1 $\beta$ gene transcription and protein maturation, the two main signals required for activation of NLRP3 [81]. In macrophages, SARS-CoV1 ORF8b robustly activates the NLRP3 inflammasome by interacting directly with the Leucine Rich Repeat domain of NLRP3 in cytosolic dot-like structures [82], suggesting another two-step model, in which inflammaging and the NLRP3 basal overactivation is the first step and SARS-CoV-2 antigen-mediated hyperactivation is the second step that triggers a cytokine storm.

In chronic diseases, hyperactivity of the inflammasome plays a dominant role in the development of type 2 diabetes and other age-related diseases [83]. Indeed, in older adults, the upregulation of two inflammasomerelated gene sets correlate with increased risk of hypertension, metabolic dysfunction, oxidative stress and mortality [84]. Individuals over the age of 85 that expressed lower levels of these inflammasome modules were less likely to die within seven years [84]. Taking together, the known effects of coronavirus proteins on $\mathrm{NAD}^{+}, \mathrm{NLRP3}$, and the two stages of inflammasome activation, these data provide a plausible explanation as to why co-morbidities positively correlate with cytokine storms and fatality in COVID-19 patients.

After age and hematological cancers, obesity is the next major risk factor for COVID-19 fatality, similar to type 2 diabetes [85]. Obesity is well known to increase the activity of NLRP3 and stimulate low grade inflammation in mice, including higher levels of serum chemokines, and lower neutralizing antibodies and effector memory $\mathrm{T}$ cells during a viral infection [86]. Accordingly, this may help explain why obesity is associated with lower survival in COVID-19, SARSCoV-1 and MERS-CoV infections, and why obesityrelated human diseases such as cardiovascular disease, chronic kidney disease, and diabetes, predispose patients to cytokine storms (Table 1) [87-89]. In addition, by causing the endothelium of the microvasculature to become leaky, obesity and type 2 diabetes, may increase the ability of SARS-CoV-2 to infect surrounding pericytes that appear to express ACE2 at levels far greater than surrounding cells [12]. 
Table 1. Risk factors for adverse outcomes in human coronavirus infections.

\begin{tabular}{lcc}
\hline Risk factor & Virus & References \\
\hline Advanced age & SARS-CoV-2, SARS-CoV-1, MERS & {$[4,175-181]$} \\
$\begin{array}{l}\text { Cardiovascular disease, hypertension } \\
\text { and coronary artery disease }\end{array}$ & SARS-CoV-2, SARS-CoV-1, MERS & {$[4,176,179,181-184]$} \\
Diabetes & & \\
Obesity & SARS-CoV-2, SARS-CoV-1, MERS & {$[4,176,182,183,185-188]$} \\
Male Sex & SARS-CoV-2, SARS-CoV-1, MERS & {$[4,182,183,189]$} \\
Respiratory diseases & SARS-CoV-2, MERS & {$[4,176,178]$} \\
Kidney disease & SARS-CoV-2, MERS & {$[4,176,181]$} \\
Immunological disorders & SARS-CoV-2, MERS & {$[4,176,187,190]$} \\
Cancer & SARS-CoV-2 & {$[4,175]$} \\
Other factors & SARS-CoV-2, SARS-CoV-1 & {$[4,179]$} \\
& SARS-CoV-2, SARS-CoV-1 & {$[4,179,180,186,191]$} \\
\hline
\end{tabular}

\section{Epigenetic changes with age}

The dysregulation of the epigenome and resulting changes in gene expression during aging are strongly implicated as biomarkers, and potentially underlying causes, of chronic disease states and of aging itself. The "relocalization of chromatin modifiers" theory of aging postulates that symptoms of aging and the loss of resilience are a result of a lifetime accumulation of epigenetic changes $[90,91]$. These changes may be caused, in part, by the redistribution of chromatin factors, such as the nuclear proteins SIRT1/6/7, HDAC1 and PARP1 away from regular loci to sites of dsDNA break repair, then back again, causing epigenetic "noise" to accumulate, which may iteratively erase cellular identity [90-94]. This process is thought to manifest as DNA methylation changes that set the pace of the biological clock in tissues and in hematopoietic cells $[95,96]$.

There is an abundance of evidence indicating that agerelated changes to the host's epigenome compromise immune cell composition and function [97] and negatively impact viral defenses [98, 99], including adaptive immune memory [100, 101]. Coronaviruses are known to mediate epigenetic alterations, potentially accelerating the rate that the immune system ages. MERS-CoV, for example, antagonizes host antigen presentation by altering DNA methylation, a mark that silences genes encoding major histocompatibility complexes [102]. Similarly, SARS-CoV-1 changes histone methylation and long non-coding RNAs, which is accompanied by the activation of interferon-response genes [103]. Measuring the DNA methylation age of immune cells and other blood cell types before, during, and after infection could help elucidate both how the aged epigenome impacts disease severity and how the virus alters the aged epigenome.

The vulnerability of the aged to SARS-CoV-2 may also have to do with the effects of the epigenome on viral entry, which is initiated by physical interaction between the viral spike glycoprotein receptor and the ACE2 cell surface protein [104]. While genetic differences in ACE2 are being pursued as a cause of COVID-19 severity [105], there is little attention being paid to epigenetic differences. In humans, ACE2 is ubiquitously expressed in epithelial tissues of the body, most highly in alveolar epithelial cells and enterocytes of the small intestine [106]. ACE2 is regulated in the body transcriptionally, post-transcriptionally, and posttranslationally [107], although its role and regulation in COVID-19 is still poorly understood.

In both mice and rats, ACE2 expression decreases with age and is associated with an increase in aortic fibrosis and inflammation [108, 109]. In healthy human lungs, ACE2 expression does not appear to change with age, [110]. Even though ACE2 is more highly expressed in the lungs of cigarette smokers [111]. A meta-analysis of COVID-19 deaths, however, did not identify smoking as a significant risk factor [4]. ACE2 promoter hypomethylation in lymphocytes correlates with transcriptional activation in patients with lupus [112], implying that transcription of ACE2 is controlled by methylation, although this mechanism has not been systematically investigated. It is known, however, that methylation at one of seven CpGs in the ACE2 promoter decreases with age and these $\mathrm{CpGs}$ are bordered by long-range promoter-enhancer contacts that may change over time [113]. Bisulfite sequencing of the ACE2 gene paired with transcriptomic and four-dimensional chromatin analyses will be necessary to understand if there is a causal relationship between promoter methylation, ACE2 expression, and disease outcome.

The elucidation of SARS pathogenesis is complicated by the fact that ACE2 is also part of the reninangiotensin system (RAS) that regulates immunity, fibrosis, blood pressure, and metabolism. ACE2 counteracts vasoconstriction caused by angiotensin 
converting enzyme (ACE) by cleaving its product, angiotensin II. Most likely due to its role in vasodilation and reducing inflammation, ACE2 partially protects against sepsis-induced- and SARS-induced severe acute lung injury in mice [114, 115] and asthma-induced airway inflammation in rats [116]. Changes in DNA methylation during aging are known to affect the RAS $[14,117,118]$. Analysis of ACE2 gene expression in the lungs of COVID-19 patients with pulmonary arterial hypertension and chronic obstructive pulmonary disease found a correlation between ACE2 expression and COVID-19 severity [111]. Thus, age-related dysregulation of ACE2 could explain why age is such a risk factor for COVID-19 complications and why cardiovascular disease and hypertension predispose patients to develop a more aggressive form of COVID-19.

The effects of ACE inhibitors, used commonly beyond middle age to control blood pressure, are generally believed to be neutral in COVID-19 [119, 120]. Due to their opposing roles in the RAS, ACE2 expression appears to increase when ACE is inhibited, likely providing a yet unknown protective function [121]. Inhibiting ACE2 expression or blocking ACE2 accessibility could prevent viral entry but may lead to vasoconstriction and hypertension. Instead, the most promising ACE2-targeted therapeutic strategy is to infuse human recombinant soluble ACE2 into the airway or bloodstream to bind the SARS-CoV-2 spike glycoprotein receptor, preventing it from binding ACE2 on host cell surfaces [122] and slowing cell infection rates.

\section{Sirtuins and NAD ${ }^{+}$}

The sirtuins are a family of $\mathrm{NAD}^{+}$-dependent lysine deacylases that control numerous aspects of stress resistance and pathogen defenses. SIRT1 is a nuclear histone deacetylase that suppresses viral replication and chronic inflammation [123]. By binding to the promoter region of ACE2, SIRT1 upregulates transcription under conditions of cell stress [124]. During aging, and perhaps particularly during the course of COVID-19, levels of $\mathrm{NAD}^{+}$decline. This is likely due to increased $\mathrm{NAD}^{+}$consumption by the $\mathrm{CD}_{3}{ }^{+}$glycohydrolase [125] and increased transcription of the poly-ADP-ribosyl transferases, PARP9, PARP10, PARP 12 and PARP14 in mice and humans infected with SARS-CoV-2 [78]. Coronaviruses also possess an ADP-ribosylhydrolase that further depletes $\mathrm{NAD}^{+}$, apparently to disrupt cell signaling, DNA repair, gene regulation and apoptosis $[14,126,127]$.

By negatively regulating activity of NLRP3, SIRT1 and the related protein SIRT2, seem to play key roles in suppressing acute lung inflammation during sepsis [75]. Mice lacking SIRT1, for example, display aggravated inflammasome activation, with increased production of lung proinflammatory mediators, including intercellular adhesion molecule 1 (ICAM-1) and high-mobility group box 1 (HMGB1), and a dramatic reduction of lung claudin- 1 and vascular endothelial-cadherin expression [128]. Further, as a result of $\mathrm{NAD}^{+}$depletion in mouse models of uncontrolled diabetes, DNA repair is blunted leading to pulmonary inflammation, senescence and fibrosis [129], which could explain why diabetics are more susceptible to COVID-19. SIRT1 also attenuates the acute inflammatory response through deacetylation of H4K16 in the TNF- $\alpha$ promoter [130]. Another nuclear sirtuin, SIRT6 attenuates NF-kB signaling by deacetylating $\mathrm{H} 3 \mathrm{~K} 9$ [131]. Thus, a decline in $\mathrm{NAD}^{+}$ and the known mis-localization of SIRT1 and SIRT6 across the genome during aging [90, 132], could be major contributors to the age-dependency of COVID19 symptoms. As such, $\mathrm{NAD}^{+}$precursors, such as NMN and NR [133], have been suggested as possible treatments for COVID-19, especially in older people [78]. Clinical studies are needed to determine if $\mathrm{NAD}^{+}$ supplementation would benefit in the early stages of SARS-CoV-2 to reduce replication or if $\mathrm{NAD}^{+}$ treatment during acute COVID-19 can hasten recovery.

\section{Biological clocks}

Over the past decade, a variety of biological clocks have been developed to predict human health and longevity more accurately than chronological age, including those based on DNA methylation patterns [95, 134-136], inflammaging [137], gene expression patterns [138], frailty $[139,140]$, serum proteins [141], and $\mathrm{IgG}$ glycosylation [142-144]. Given that these clocks provide a quantitative measure of the rate of aging of an individual and their overall resilience, biological clocks may be useful for identifying at-risk populations and for predicting, within those populations, who will most likely progress to severe COVID-19.

\section{Epigenetic clocks}

Estimates based on twin studies place the contribution of non-genetic factors on predicted COVID-19 phenotype at $50 \%$ [145] and on total disease burden in old age at approximately $80 \%$ [146]. Indeed, lifestyle factors that affect the epigenome such as calorie intake may increase the susceptibility to COVID-19. Epigenetic age is greater than chronological age in various disease contexts and lower in long-lived humans, providing strong evidence that epigenetic age reflects biological age [134, 147]. Age-associated changes to the epigenome have profound effects on 
the immune system, including $\mathrm{T}$ cell function, cytokine production and macrophage pattern recognition. DNA methylation is believed to set the pace of the aging clock in several mammalian tissues, including hematopoietic cells of the immune system $[95,96]$. Epigenetic clocks that measure DNA methylation at specific $\mathrm{CpG}$ sites are the most widely used measure of biological age and disease susceptibility [134, 147]. Restoration of the thymus using a drug cocktail of metformin, growth hormone and dehydroepiandrosterone led to the reversal of features of immunosenescence, specifically increasing naïve $T$ cells and a decreasing senescent $P D-1^{+} T$ cells, along with the reversal of the epigenetic clock by about 1.5 years [96]. Epigenetic age may be a better biomarker than chronological age in predicting how variation in lifestyle factors and age-associated comorbidities increase susceptibility to COVID-19 and may also help determine if COVID-19 infection accelerates epigenetic age. We hope to test both by measuring the DNA methylation ages of peripheral blood samples from thousands of COVID-19 patients and correlating methylation age measurements with clinical outcomes.

\section{Glycosylation clocks}

Changes in glycosylation during aging may also predispose older individuals to severe COVID-19 [148]. Glycosylation is the enzymatic process by which carbohydrates called glycans, such as sialic acid, mannose and fucose, are covalently attached to proteins or lipids, typically on the cell surface or in the bloodstream. An individual's repertoire of glycans - a notable example being the type of $\mathrm{N}$-glycans attached to immunoglobulins [149] - changes with age and environmental factors, such as smoking and poor diet [148]. The type of glycans attached to IgGs affects their pro- and anti-inflammatory properties [150]. Decreased galactosylation of IgGs is associated with central adiposity [151] and inflammaging in the context of diabetes [152]. Biological clocks based on IgG glycosylation are able to predict chronological age within 10 years, and can be improved by inclusion of clinical parameters [144]. Thus, changes to the glycome with age could serve both as an indicator of biological age and could potentially predict COVID19 severity.

Aging also changes the glycome via non-enzymatic glycation, by which reducing sugars circulating in extracellular compartments covalently bind to proteins and lipids to form advanced glycation end products (AGEs). AGEs are present in large quantities in the Western diet, and greater consumption of dietary AGEs increases serum TNF- $\alpha$ [153]. AGEs tend to accumulate under hyperglycemic conditions and contribute to the pathology of many age-related disease such as type 2 diabetes and obesity [154]. AGEs may increase COVID-19 severity in the aged by inhibiting the NLRP3 inflammasome during the early stages of viral infection [155] when the inflammatory program is activated by the SARS-CoV-1 3a protein [156]. AGEs also play a role in activating pro-coagulation pathways [154], potentially contributing to the DIC observed in COVID-19 patients.

Glycosylation patterns specific to older people may also impact viral entry. The SARS-CoV-2 spike protein is heavily glycosylated [157], modifications that are highly conserved between coronaviruses. SARS-CoV-2 shares 20 out of 22 of glycosylated Nlinkages with SARS-CoV-1 [157]. In the case of the human influenza virus, variation in sialic acid structures on the surface of cells lining the upper and lower respiratory tracts dictates tropism and agedependent binding efficiency of the virus [158] but how changes in the coronavirus spike protein during aging might affect viral transmission and pathogenesis is not yet known. If we are to use glycation as a prognostic marker for COVID-19, it will be necessary to map the glycome in hundreds of patient samples with varying degrees of COVID-19 severity, including asymptomatic individuals.

\section{Immune clocks}

Between individuals, heterogeneity of the immune system increases during aging [18] and may explain differences in susceptibility to infectious diseases. A biological clock based on the immune system called IMM-AGE was recently developed that predicts allcause mortality in older adults more accurately than even DNA methylation clocks [137]. IMM-AGE overcomes the limitation of inter-human immune heterogeneity by tracking immune cell frequencies and gene expression changes longitudinally within individuals and then computationally predicting how an individual's homeostatic immune state changes over time. Though individuals exhibit variation in immune cell-type composition, these changes fall into three stages that converge on a common "attractor point" that correlates with age and is indicative of overall physiological resilience [137]. In this way, IMM-AGE measures the entropic relationship between age and immune system remodeling, the rate of which can predict survival. Because IMM-AGE is even able to capture and predict the effect of inflammaging on the cardiovascular system, and because COVID-19 fatality is so closely tied to cardiovascular disease and inflammaging, this clock may prove to be the most accurate at identifying COVID-19-susceptible individuals. More 
studies are still needed to determine if and how viral infections alter these and other biological clocks, and whether variation in biological age predicts COVID-19 severity.

\section{Geroprotectors to improve immunity}

Advanced age is by far the greatest risk factor for COVID-19 fatality independent of underlying comorbidities [4]. This striking fact has led many researchers to speculate whether molecules that target aging itself, called geroprotectors, could be used to combat infections in older people [5, 159]. Primarily via its regulation of cellular metabolism, the mammalian target of rapamycin (mTOR) signaling pathway controls several immune functions such as antigen presentation, immune activation, differentiation, and cytokine production [160, 161]. Low dose mTOR inhibitors exhibit a hormetic effect in older people, seemingly improving immunity and reducing rates of infection $[162,163]$. People over 65 years old who took mTOR inhibitors for six weeks responded more robustly when challenged with an influenza vaccine and showed reduced levels of the T-cell exhaustion marker PD-1 [162]. In a similar clinical trial, protection from infection and an increase in anti-viral gene expression was observed even a year after the 6-week course of
mTOR complex 1 (mTORC1) inhibitors [163], though the result was not reproduced in a Phase 3 trial.

Metformin, a blood glucose lowering geroprotector that activates 5'AMP-activated protein kinase (AMPK) and inhibits the mTOR pathway, has also been suggested as a possible drug to combat severe SARS-CoV-2 infection in older people. In addition to its potential insulin-sensitizing antiviral effect [164], metformin confers a myriad of anti-aging benefits including improving mitochondrial metabolism, decreasing inflammatory cytokines, protecting against genomic instability and decreasing cellular senescence [165], which may bolster the aging body's resistance to COVID-19. Results from the ongoing Targeting Aging with MEtformin (TAME) clinical trials and others should reveal whether these anti-aging drugs are protective against SARS-CoV-2 infection $[165,166]$.

\section{Where do we go from here?}

Why SARS-CoV-2 infections are more severe and fatal in the aged is not known, but viable hypotheses are emerging that include changes to the immune cell repertoire, the epigenome, $\mathrm{NAD}^{+}$levels, inflammasome activity, biological clocks, and covalent modifications of human and viral proteins (Figure 3). Much

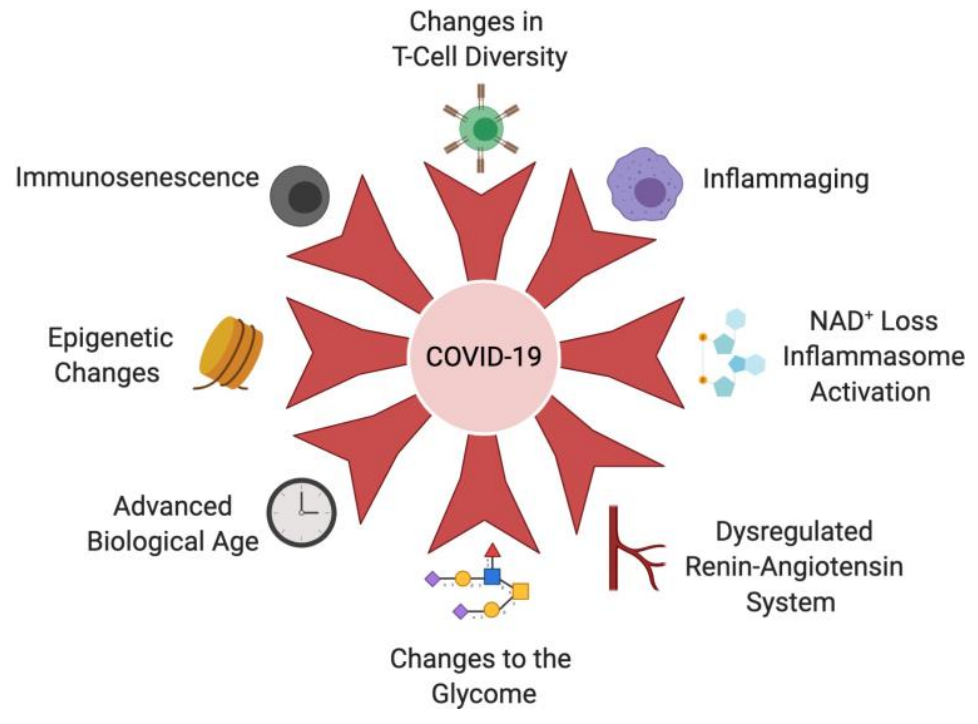

Figure 3. Age-related changes that increase COVID-19 susceptibility. The aging immune system undergoes immunosenescence, Tcell diversity alterations and chronic activation of the innate immune system known as inflammaging. These hallmarks of the aging immune system cripple the body's ability to clear the SARS-CoV-2 virus, initiate and sustain cytokine storms that cause acute organ injury, DIC and multi-organ failure. An age-associated decline in NAD+ results in derepression of NLRP3 and inflammasome in older people, further exacerbating the cytokine storm. Coronaviruses also possess an ADP-ribosylhydrolase that further depletes already-low NAD+levels in older people. Leveling of the epigenetic landscape during aging results in changes in immune cell composition and function that decrease the immune system's ability to mount a response to infection. Epigenetic dysregulation of ACE2 may also impact increased viral loads in older people. Dysregulation of the RAS during aging and in the context of age-associated disease, such as cardiovascular disease, hypertension, COPD and obesity, contributes to severity of COVID-19 infection. The glycome which controls a variety of immune signaling pathways changes during aging and in the context of metabolic diseases. For example, decreases in IgG galactosylation contribute to chronic inflammation. Biological clocks that measure different biomarkers of biological age may explain increased COVID-19 susceptibility more accurately than advanced chronological age. Created with BioRender. 
remains to be elucidated, still. Besides understanding the basis of the cytokine storms and coagulopathy, it is not known why SARS-CoV-2 so easily damages such a broad array of tissues in older people but rarely in the young. Nor is it clear whether older people develop stronger or weaker functional immunity during seroconversion, or how long their protection will last compared to younger people. In the aged, immune responses to vaccination are also often weak or defective [18, 167, 168], whereas autoimmunity increases [169]. Therefore, in designing vaccines against SARS-CoV-2, it will be important to consider that older people may not respond as well to vaccines as young people. Studies that follow the long-term consequences of SARS-CoV-2 infection in older people will also be critical to understand the long-term health consequences of COVID-19 pathology, such as fibrosis and scaring of the lungs, micro-ischemic events, cardiopulmonary dysfunction, and neuropsychological disability [170]. These could significantly reduce viral resistance and lifespan in older and middle-aged people who recover from severe cases of COVID-19. The most exciting and potentially impactful technologies to combat COVID-19 and other viral pandemics are those that activate the body's defenses against aging $[5,166]$. Eventually, with advances in the field, it may even be possible to reverse the age of cells and tissues [171174] so that high-risk older individuals can respond to viral infections as though they were young.

\section{Abbreviations}

SARS-CoV-1: severe acute respiratory syndrome coronavirus identified in 2003; SARS-CoV-2: severe acute respiratory syndrome coronavirus identified in 2019; MERS-CoV: middle east respiratory syndrome coronavirus; COVID-19: coronavirus disease 2019; ARDS: acute respiratory distress syndrome; TLR: Tolllike receptor; TCR: T cell receptor; DIC: disseminated intervascular coagulation; IL: interleukin; ACE: angiotensin-converting enzyme; ACE2: angiotensinconverting enzyme 2; RAS: renin-angiotensin system; SIRT1-7: sirtuin 1-7; AGE: advanced glycan end product; NLRP3: NOD-, LRR- and pyrin domaincontaining protein 3; IMM-AGE: immune age; PARP: poly (ADP-ribose) polymerase; $\mathrm{NAD}^{+}$: nicotinamide adenine dinucleotide; NMN: nicotinamide mononucleotide; NR: nicotinamide riboside; SARS-CoV-1 ORF3a: SARS-CoV-1 open reading frame 3a; NK cell: natural killer cell; NF- $\mathrm{kB}$ : nuclear factor kappa-lightchain-enhancer of activated B cells; PD-1: programmed cell death protein 1; IgG: immunoglobulin $\mathrm{G}$; IgE: immunoglobulin E; AM: alveolar macrophages; CRP: C-reactive protein; CMV: cytomegalovirus; GCSF: granulocyte-colony stimulating factor; IP-10: interferon gamma-induced protein 10; MCP-1: monocyte chemoattractant protein-1; MIP-1 $\alpha$ : macrophage inflammatory protein 1 alpha; TNF- $\alpha$ : tumor necrosis factor alpha; mTOR: mammalian target of rapamycin; mTORC1: mammalian target of rapamycin 1; AMPK: 5' AMP-activated protein kinase; TAME: targeting aging with metformin; HDAC: histone deacetylases; CCR1: C-C Motif Chemokine Receptor 1; CXCR2: CXC chemokine receptor 2; ICAM-1: intercellular adhesion molecule 1; HMGB1: high mobility group box 1 .

\section{ACKNOWLEDGMENTS}

We thank the first responders, essential employees, public health leaders, physicians and scientists who are continuing to work tirelessly to treat COVID-19 patients, protect vulnerable populations, and prevent the spread of this virus.

\section{CONFLICTS OF INTEREST}

AM and MM declare no conflicts. DAS is a board member, equity owner and inventor on patents licensed to MetroBiotech, Liberty Biosecurity, and Jumpstart Fertility, both developing molecules for the treatment of diseases by raising $\mathrm{NAD}^{+}$levels. Other affiliations are listed here https://genetics.med.harvard.edu/sinclairtest/people/sinclair-other.php.

\section{FUNDING}

DAS is supported by the Paul F. Glenn Foundation for Medical Research and NIH grants R37 AG028730 and R01 DK100263.

\section{REFERENCES}

1. Zhu N, Zhang D, Wang W, Li X, Yang B, Song J, Zhao X, Huang B, Shi W, Lu R, Niu P, Zhan F, Ma X, et al, and China Novel Coronavirus Investigating and Research Team. A novel coronavirus from patients with pneumonia in China, 2019. N Engl J Med. 2020; 382:727-33. https://doi.org/10.1056/NEJMoa2001017 PMID: $\underline{31978945}$

2. Worldometer. 2020. https://www.worldometers. info/coronavirus/coronavirus-age-sex-demographics/

3. World-Health-Organization. 2020. Coronavirus disease 2019 (COVID-19) Situation Report.

4. Williamson E, Walker AJ, Bhaskaran KJ, Bacon S, Bates C, Morton CE, Curtis HJ, Mehrkar A, Evans D, Inglesby P, Cockburn J, Mcdonald HI, MacKenna B, et al. 
OpenSAFELY: factors associated with COVID-19-related hospital death in the linked electronic health records of 17 million adult NHS patients. medRxiv. 2020.

5. Santesmasses D, Castro JP, Zenin AA, Shindyapina AV, Gerashchenko MV, Zhang B, Kerepesi C, Yim SH, Fedichev PO, Gladyshev VN. COVID-19 is an emergent disease of aging. medRxiv. 2020.

https://doi.org/10.1101/2020.04.15.20060095

6. Geller C, Varbanov M, Duval RE. Human coronaviruses: insights into environmental resistance and its influence on the development of new antiseptic strategies. Viruses. 2012; 4:3044-68. https://doi.org/10.3390/v4113044 PMID:23202515

7. Yan R, Zhang Y, Li Y, Xia L, Guo Y, Zhou Q. Structural basis for the recognition of SARS-CoV-2 by full-length human ACE2. Science. 2020; 367:1444-48.

https://doi.org/10.1126/science.abb2762

PMID: $\underline{2132184}$

8. Wölfel $R$, Corman VM, Guggemos $W$, Seilmaier $M$, Zange S, Müller MA, Niemeyer D, Jones TC, Vollmar $P$, Rothe C, Hoelscher M, Bleicker T, Brünink $S$, et al. Virological assessment of hospitalized patients with COVID-2019. Nature. 2020. [Epub ahead of print]. https://doi.org/10.1038/s41586-020-2196-x PMID: 32235945

9. Wu C, Chen X, Cai Y, Xia J, Zhou X, Xu S, Huang H, Zhang L, Zhou X, Du C, Zhang Y, Song J, Wang S, et al. Risk Factors Associated With Acute Respiratory Distress Syndrome and Death in Patients With Coronavirus Disease 2019 Pneumonia in Wuhan, China. JAMA Intern Med. 2020:e200994. [Epub ahead of print]. https://doi.org/10.1001/jamainternmed.2020.0994 PMID:32167524

10. Zhang LN, Sun JP, Xue XY, Wang JX. Exogenous pulmonary surfactant for acute respiratory distress syndrome in adults: a systematic review and metaanalysis. Exp Ther Med. 2013; 5:237-42.

https://doi.org/10.3892/etm.2012.746

PMID:23251275

11. Varga Z, Flammer AJ, Steiger $P$, Haberecker $M$, Andermatt R, Zinkernagel AS, Mehra MR, Schuepbach RA, Ruschitzka F, Moch H. Endothelial cell infection and endotheliitis in COVID-19. Lancet. 2020; 395:1417-18. https://doi.org/10.1016/S0140-6736(20)30937-5 PMID:32325026

12. He L, Mae MA, Sun Y, Muhl L, Nahar K, Liebanas EV, Fagerlund MJ, Oldner A, Liu J, Genove G, Pietila R, Zhang L, Xie $Y$, et al. Pericyte-specific vascular expression of SARS-CoV-2 receptor ACE2 - implications for microvascular inflammation and hypercoagulopathy in COVID-19 patients. bioRxiv. 2020. https://doi.org/10.1101/2020.05.11.088500

13. Channappanavar R, Perlman S. Pathogenic human coronavirus infections: causes and consequences of cytokine storm and immunopathology. Semin Immunopathol. 2017; 39:529-39. https://doi.org/10.1007/s00281-017-0629-x PMID:28466096

14. Kouhpayeh S, Shariati L, Boshtam M, Rahimmanesh I, Mirian M, Zeinalian M, Salari-jazi A, Khanahmad N, Damavandi MS, Sadeghi P, Khanahmad H. The Molecular Story of COVID-19; NAD+ Depletion Addresses All Questions in this Infection. Preprints. 2020. https://doi.org/10.20944/preprints202003.0346.v1

15. Liu Y, Yan LM, Wan L, Xiang TX, Le A, Liu JM, Peiris M, Poon LLM, Zhang W. Viral dynamics in mild and severe cases of COVID-19. Lancet Infect Dis. 2020. [Epub ahead of print]. https://doi.org/10.1016/S1473-3099(20)30232-2 PMID: $\underline{32199493}$

16. Fulop $T$, Larbi A, Dupuis $G$, Le Page A, Frost EH, Cohen AA, Witkowski JM, Franceschi C. Immunosenescence and inflamm-aging as two sides of the same coin: friends or foes? Front Immunol. 2018; 8:1960. https://doi.org/10.3389/fimmu.2017.01960 PMID:29375577

17. Franceschi C, Salvioli S, Garagnani P, de Eguileor $M$, Monti D, Capri M. Immunobiography and the heterogeneity of immune responses in the elderly: a focus on inflammaging and trained immunity. Front Immunol. 2017; 8:982.

https://doi.org/10.3389/fimmu.2017.00982 PMID:28861086

18. Shen-Orr SS, Furman D. Variability in the immune system: of vaccine responses and immune states. Curr Opin Immunol. 2013; 25:542-47.

https://doi.org/10.1016/j.coi.2013.07.009 PMID:23953808

19. Franceschi $C$, Bonafè $M$, Valensin $S$, Olivieri $F$, De Luca M, Ottaviani E, De Benedictis G. Inflamm-aging. An evolutionary perspective on immunosenescence. Ann N Y Acad Sci. 2000; 908:244-54. https://doi.org/10.1111/j.1749-6632.2000.tb06651.x PMID:10911963

20. Hinojosa E, Boyd AR, Orihuela CJ. Age-associated inflammation and toll-like receptor dysfunction prime the lungs for pneumococcal pneumonia. J Infect Dis. 2009; 200:546-54.

https://doi.org/10.1086/600870

PMID: 19586419

21. Li G, Fan $Y$, Lai $Y$, Han T, Li Z, Zhou P, Pan P, Wang W, Hu $D$, Liu $X$, Zhang $Q$, Wu J. Coronavirus infections and 
immune responses. J Med Virol. 2020; 92:424-32. https://doi.org/10.1002/jmv.25685

PMID:31981224

22. Shi Y, Wang Y, Shao C, Huang J, Gan J, Huang X, Bucci E, Piacentini M, Ippolito G, Melino G. COVID-19 infection: the perspectives on immune responses. Cell Death Differ. 2020; 27:1451-54.

https://doi.org/10.1038/s41418-020-0530-3

PMID:32205856

23. Kovacs EJ, Boe DM, Boule LA, Curtis BJ. Inflammaging and the lung. Clin Geriatr Med. 2017; 33:459-71.

https://doi.org/10.1016/i.cger.2017.06.002

PMID:28991644

24. Shaw AC, Joshi S, Greenwood H, Panda A, Lord JM. Aging of the innate immune system. Curr Opin Immunol. 2010; 22:507-13.

https://doi.org/10.1016/j.coi.2010.05.003

PMID:20667703

25. Liao M, Liu Y, Yuan J, Wen Y, Xu G, Zhao J, Cheng L, Li J, Wang X, Wang F, Liu L, Amit I, Zhang S, et al. Single-cell landscape of bronchoalveolar immune cells in patients with COVID-19. Nature medicine. 2020. https://doi.org/10.1038/s41591-020-0901-9

26. Liu L, Wei $Q$, Lin $Q$, Fang J, Wang $H$, Kwok $H$, Tang $H$, Nishiura K, Peng J, Tan Z, Wu T, Cheung KW, Chan KH, et al. Anti-spike IgG causes severe acute lung injury by skewing macrophage responses during acute SARS-CoV infection. JCl Insight. 2019; 4:e123158.

https://doi.org/10.1172/jci.insight.123158

PMID: $\underline{30830861}$

27. Nicholls JM, Poon LL, Lee KC, Ng WF, Lai ST, Leung CY, Chu CM, Hui PK, Mak KL, Lim W, Yan KW, Chan KH, Tsang NC, et al. Lung pathology of fatal severe acute respiratory syndrome. Lancet. 2003; 361:1773-78.

https://doi.org/10.1016/s0140-6736(03)13413-7

PMID: 12781536

28. Przemska-Kosicka A, Childs CE, Maidens C, Dong $H$, Todd S, Gosney MA, Tuohy KM, Yaqoob P. Agerelated changes in the natural killer cell response to seasonal influenza vaccination are not influenced by a synbiotic: a randomised controlled trial. Front Immunol. 2018; 9:591.

https://doi.org/10.3389/fimmu.2018.00591

PMID:29662493

29. Mahbub S, Brubaker AL, Kovacs EJ. Aging of the innate immune system: an update. Curr Immunol Rev. 2011; 7:104-15.

https://doi.org/10.2174/157339511794474181

PMID:21461315

30. Sapey E, Patel JM, Greenwood HL, Walton GM, Hazeldine J, Sadhra C, Parekh D, Dancer RC,
Nightingale $\mathrm{P}$, Lord JM, Thickett DR. Pulmonary infections in the elderly lead to impaired neutrophil targeting, which is improved by simvastatin. Am J Respir Crit Care Med. 2017; 196:1325-36. https://doi.org/10.1164/rccm.201704-08140C PMID:28657793

31. Glass WG, Subbarao K, Murphy B, Murphy PM. Mechanisms of host defense following severe acute respiratory syndrome-coronavirus (SARS-CoV) pulmonary infection of mice. J Immunol. 2004; 173:4030-39.

https://doi.org/10.4049/jimmunol.173.6.4030 PMID:15356152

32. Xu F, Laguna L, Sarkar A. Aging-related changes in quantity and quality of saliva: where do we stand in our understanding? J Texture Stud. 2019; 50:27-35. https://doi.org/10.1111/itxs.12356 PMID:30091142

33. Paulsen F. Cell and molecular biology of human lacrimal gland and nasolacrimal duct mucins. Int Rev Cytol. 2006; 249:229-79. https://doi.org/10.1016/S0074-7696(06)49005-7 PMID:16697285

34. Palmer DB. The effect of age on thymic function. Front Immunol. 2013; 4:316.

https://doi.org/10.3389/fimmu.2013.00316 PMID:24109481

35. Majumdar S, Nandi D. Thymic atrophy: experimental studies and therapeutic interventions. Scand J Immunol. 2018; 87:4-14. https://doi.org/10.1111/sji.12618 PMID:28960415

36. Youm YH, Kanneganti TD, Vandanmagsar B, Zhu X, Ravussin A, Adijiang A, Owen JS, Thomas MJ, Francis J, Parks JS, Dixit VD. The Nlrp3 inflammasome promotes age-related thymic demise and immunosenescence. Cell Rep. 2012; 1:56-68.

https://doi.org/10.1016/j.celrep.2011.11.005 PMID:22832107

37. Ongrádi J, Kövesdi V. Factors that may impact on immunosenescence: an appraisal. Immun Ageing. 2010; 7:7. https://doi.org/10.1186/1742-4933-7-7 PMID:20546588

38. Ron-Harel N, Notarangelo G, Ghergurovich JM, Paulo JA, Sage PT, Santos D, Satterstrom FK, Gygi SP, Rabinowitz JD, Sharpe AH, Haigis MC. Defective respiration and one-carbon metabolism contribute to impaired naïve T cell activation in aged mice. Proc Natl Acad Sci USA. 2018; 115:13347-52. https://doi.org/10.1073/pnas.1804149115 PMID:30530686

39. Salam N, Rane S, Das R, Faulkner M, Gund R, Kandpal U, Lewis V, Mattoo H, Prabhu S, Ranganathan V, Durdik 
J, George A, Rath S, Bal V. T cell ageing: effects of age on development, survival \& function. Indian J Med Res. 2013; 138:595-608.

PMID:24434315

40. Yoshida K, Cologne JB, Cordova K, Misumi M, Yamaoka M, Kyoizumi S, Hayashi T, Robins $H$, Kusunoki Y. Aging-related changes in human t-cell repertoire over 20years delineated by deep sequencing of peripheral t-cell receptors. Exp Gerontol. 2017; 96:29-37.

https://doi.org/10.1016/j.exger.2017.05.015 PMID:28535950

41. Hashimoto $\mathrm{K}$, Kouno $\mathrm{T}$, Ikawa $\mathrm{T}$, Hayatsu $\mathrm{N}$, Miyajima $\mathrm{Y}$, Yabukami H, Terooatea T, Sasaki T, Suzuki T, Valentine M, Pascarella G, Okazaki Y, Suzuki $H$, et al. Single-cell transcriptomics reveals expansion of cytotoxic CD4 T cells in supercentenarians. Proc Natl Acad Sci USA. 2019; 116:24242-51.

https://doi.org/10.1073/pnas.1907883116

PMID:31719197

42. Diao B, Wang C, Tan Y, Chen X, Liu Y, Ning L, Chen L, Li $M$, Liu $Y$, Wang $G$, Yuan Z, Feng $Z$, Zhang $Y$, et al. Reduction and functional exhaustion of $T$ cells in patients with coronavirus disease 2019 (COVID-19). Front Immunol. 2020; 11:827.

https://doi.org/10.3389/fimmu.2020.00827 PMID:32425950

43. Zhou $P$, Yang $X L$, Wang $X G$, Hu B, Zhang $L$, Zhang $W$, Si $H R$, Zhu Y, Li B, Huang CL, Chen HD, Chen J, Luo Y, et al. A pneumonia outbreak associated with a new coronavirus of probable bat origin. Nature. 2020; 579:270-73.

https://doi.org/10.1038/s41586-020-2012-7 PMID: 32015507

44. Zheng HY, Zhang M, Yang CX, Zhang N, Wang XC, Yang $X P$, Dong $X Q$, Zheng YT. Elevated exhaustion levels and reduced functional diversity of $T$ cells in peripheral blood may predict severe progression in COVID-19 patients. Cell Mol Immunol. 2020; 17:541-43. https://doi.org/10.1038/s41423-020-0401-3 PMID:32203186

45. Huang $C$, Wang $Y$, Li X, Ren L, Zhao J, Hu Y, Zhang L, Fan G, Xu J, Gu X, Cheng Z, Yu T, Xia J, et al. Clinical features of patients infected with 2019 novel coronavirus in wuhan, China. Lancet. 2020; 395:497-506. https://doi.org/10.1016/S0140-6736(20)30183-5 PMID:31986264

46. Aiello A, Farzaneh F, Candore G, Caruso C, Davinelli S, Gambino CM, Ligotti ME, Zareian N, Accardi G. Immunosenescence and its hallmarks: how to oppose aging strategically? a review of potential options for therapeutic intervention. Front Immunol. 2019; 10:2247. https://doi.org/10.3389/fimmu.2019.02247 PMID:31608061

47. Pawelec G. Immunosenenescence: role of cytomegalovirus. Exp Gerontol. 2014; 54:1-5. https://doi.org/10.1016/j.exger.2013.11.010 PMID:24291068

48. Bartlett DB, Firth CM, Phillips AC, Moss $P$, Baylis D, Syddall H, Sayer AA, Cooper C, Lord JM. The agerelated increase in low-grade systemic inflammation (inflammaging) is not driven by cytomegalovirus infection. Aging Cell. 2012; 11:912-15. https://doi.org/10.1111/i.1474-9726.2012.00849.x PMID:22708923

49. Bellon $M$, Nicot C. Telomere dynamics in immune senescence and exhaustion triggered by chronic viral infection. Viruses. 2017; 9:289. https://doi.org/10.3390/v9100289 PMID:28981470

50. Frasca $D$, Diaz $A$, Romero $M$, Blomberg $B B$. The generation of memory $B$ cells is maintained, but the antibody response is not, in the elderly after repeated influenza immunizations. Vaccine. 2016; 34:2834-40. https://doi.org/10.1016/j.vaccine.2016.04.023 PMID:27108193

51. Caruso C, Buffa S, Candore G, Colonna-Romano G, Dunn-Walters D, Kipling D, Pawelec G. Mechanisms of immunosenescence. Immun Ageing. 2009; 6:10. https://doi.org/10.1186/1742-4933-6-10 PMID:19624841

52. Gudelj I, Lauc G, Pezer M. Immunoglobulin G glycosylation in aging and diseases. Cell Immunol. 2018; 333:65-79. https://doi.org/10.1016/j.cellimm.2018.07.009 PMID:30107893

53. Alves AS, Ishimura ME, Duarte YA, Bueno V. Parameters of the immune system and vitamin $D$ levels in old individuals. Front Immunol. 2018; 9:1122. https://doi.org/10.3389/fimmu.2018.01122 PMID:29910802

54. Meehan M, Penckofer S. The role of vitamin D in the aging adult. J Aging Gerontol. 2014; 2:60-71. https://doi.org/10.12974/2309-6128.2014.02.02.1 PMID:25893188

55. Sundaram ME, Coleman LA. Vitamin D and influenza. Adv Nutr. 2012; 3:517-25. https://doi.org/10.3945/an.112.002162 PMID:22797987

56. Martineau AR, Hanifa Y, Witt KD, Barnes NC, Hooper RL, Patel M, Stevens N, Enayat Z, Balayah Z, Syed A, Knight A, Jolliffe DA, Greiller $C L$, et al. Double-blind randomised controlled trial of vitamin D3 
supplementation for the prevention of acute respiratory infection in older adults and their carers (ViDiFlu). Thorax. 2015; 70:953-60.

https://doi.org/10.1136/thoraxinl-2015-206996

PMID:26063508

57. Bergman P, Norlin AC, Hansen S, Björkhem-Bergman L. Vitamin $D$ supplementation to patients with frequent respiratory tract infections: a post hoc analysis of a randomized and placebo-controlled trial. BMC Res Notes. 2015; 8:391.

https://doi.org/10.1186/s13104-015-1378-3

PMID:26319134

58. Arihiro $S$, Nakashima A, Matsuoka M, Suto S, Uchiyama K, Kato T, Mitobe J, Komoike N, Itagaki M, Miyakawa Y, Koido S, Hokari A, Saruta M, et al. Randomized trial of vitamin $D$ supplementation to prevent seasonal influenza and upper respiratory infection in patients with inflammatory bowel disease. Inflamm Bowel Dis. 2019; 25:1088-95.

https://doi.org/10.1093/ibd/izy346

PMID:30601999

59. Martineau AR, Jolliffe DA, Greenberg L, Aloia JF, Bergman P, Dubnov-Raz G, Esposito S, Ganmaa D, Ginde AA, Goodall EC, Grant CC, Janssens W, Jensen $\mathrm{ME}$, et al. Vitamin $\mathrm{D}$ supplementation to prevent acute respiratory infections: individual participant data metaanalysis. Health Technol Assess. 2019; 23:1-44.

https://doi.org/10.3310/hta23020

PMID:30675873

60. Terpos E, Ntanasis-Stathopoulos I, Elalamy I, Kastritis E, Sergentanis TN, Politou M, Psaltopoulou T, Gerotziafas $G$, Dimopoulos MA. Hematological findings and complications of COVID-19. Am J Hematol. 2020. [Epub ahead of print].

https://doi.org/10.1002/ajh.25829

PMID: $\underline{32282949}$

61. Weaver LK, Behrens EM. Weathering the storm: improving therapeutic interventions for cytokine storm syndromes by targeting disease pathogenesis. Curr Treatm Opt Rheumatol. 2017; 3:33-48.

https://doi.org/10.1007/s40674-017-0059-x

PMID:28944163

62. Magro C, Mulvey JJ, Berlin D, Nuovo G, Salvatore S, Harp J, Baxter-Stoltzfus A, Laurence J. Complement associated microvascular injury and thrombosis in the pathogenesis of severe COVID-19 infection: a report of five cases. Transl Res. 2020. [Epub ahead of print]. https://doi.org/10.1016/j.trsl.2020.04.007 PMID: $\underline{32299776}$

63. Mehta P, McAuley DF, Brown M, Sanchez E, Tattersall RS, Manson JJ, and HLH Across Speciality Collaboration, UK. COVID-19: consider cytokine storm syndromes and immunosuppression. Lancet. 2020; 395:1033-34.
https://doi.org/10.1016/S0140-6736(20)30628-0 PMID: $\underline{32192578}$

64. Coomes EA, Haghbayan H. Interleukin-6 in COVID-19: A Systematic Review and Meta-Analysis. medRxiv. 2020. https://doi.org/10.1101/2020.03.30.20048058

65. Kotronia E, Wannamethee SG, Papacosta AO, Whincup PH, Lennon LT, Visser M, Kapila YL, Weyant RJ, Ramsay SE. Poor oral health and inflammatory, haemostatic and cardiac biomarkers in older age: Results from two studies in the UK and USA. J Gerontol A Biol Sci Med Sci. 2020:glaa096. [Epub ahead of print]. https://doi.org/10.1093/gerona/glaa096 PMID:32306041

66. Zhang C, Wu Z, Li JW, Zhao H, Wang GQ. The cytokine release syndrome (CRS) of severe COVID-19 and Interleukin-6 receptor (IL-6R) antagonist Tocilizumab may be the key to reduce the mortality. Int J Antimicrob Agents. 2020:105954. [Epub ahead of print]. https://doi.org/10.1016/j.ijantimicag.2020.105954 PMID: 32234467

67. Paranjpe I, Russak A, De Freitas JK, Lala A, Miotto R, Vaid A, Johnson KW, Danieletto M, Golden E, Meyer D, Singh M, Somani $S$, Manna $S$, et al. Clinical Characteristics of Hospitalized Covid-19 Patients in New York City. medRxiv. 2020. https://doi.org/10.1101/2020.04.19.20062117

68. Sanada F, Taniyama Y, Muratsu J, Otsu R, Shimizu H, Rakugi $\mathrm{H}$, Morishita R. Source of chronic inflammation in aging. Front Cardiovasc Med. 2018; 5:12. https://doi.org/10.3389/fcvm.2018.00012 PMID:29564335

69. Buford TW, Carter CS, VanDerPol WJ, Chen D, Lefkowitz EJ, Eipers P, Morrow CD, Bamman MM. Composition and richness of the serum microbiome differ by age and link to systemic inflammation. Geroscience. 2018; 40:257-68. https://doi.org/10.1007/s11357-018-0026-y PMID:29869736

70. Mirsoian A, Bouchlaka MN, Sckisel GD, Chen M, Pai CC, Maverakis E, Spencer RG, Fishbein KW, Siddiqui S, Monjazeb AM, Martin B, Maudsley S, Hesdorffer C, et al. Adiposity induces lethal cytokine storm after systemic administration of stimulatory immunotherapy regimens in aged mice. J Exp Med. 2014; 211:2373-83.

https://doi.org/10.1084/jem.20140116 PMID:25366964

71. Krabbe KS, Pedersen $M$, Bruunsgaard $H$. Inflammatory mediators in the elderly. Exp Gerontol. 2004; 39:687-99. https://doi.org/10.1016/j.exger.2004.01.009 PMID:15130663 
72. Rea IM, Gibson DS, McGilligan V, McNerlan SE, Alexander HD, Ross OA. Age and age-related diseases: role of inflammation triggers and cytokines. Front Immunol. 2018; 9:586.

https://doi.org/10.3389/fimmu.2018.00586

PMID:29686666

73. Stout-Delgado HW, Cho SJ, Chu SG, Mitzel DN, Villalba J, El-Chemaly S, Ryter SW, Choi AM, Rosas IO. Agedependent susceptibility to pulmonary fibrosis is associated with NLRP3 inflammasome activation. Am J Respir Cell Mol Biol. 2016; 55:252-63. https://doi.org/10.1165/rcmb.2015-02220C PMID:26933834

74. Zhao C, Zhao W. NLRP3 inflammasome-a key player in antiviral responses. Front Immunol. 2020; 11:211. https://doi.org/10.3389/fimmu.2020.00211 PMID:32133002

75. He M, Chiang HH, Luo H, Zheng Z, Qiao Q, Wang L, Tan M, Ohkubo R, Mu WC, Zhao S, Wu H, Chen D. An acetylation switch of the NLRP3 inflammasome regulates aging-associated chronic inflammation and insulin resistance. Cell Metab. 2020; 31:580-591.e5.

https://doi.org/10.1016/j.cmet.2020.01.009

PMID:32032542

76. Massudi H, Grant R, Braidy N, Guest J, Farnsworth B, Guillemin GJ. Age-associated changes in oxidative stress and NAD+ metabolism in human tissue. PLoS One. 2012; $7: \mathrm{e} 42357$.

https://doi.org/10.1371/journal.pone.0042357 PMID:22848760

77. Lantier L, Williams AS, Hughey CC, Bracy DP, James FD, Ansari MA, Gius D, Wasserman DH. SIRT2 knockout exacerbates insulin resistance in high fat-fed mice. PLoS One. 2018; 13:e0208634.

https://doi.org/10.1371/journal.pone.0208634 PMID:30533032

78. Heer CD, Sanderson DJ, Alhammad YM, Schmidt MS, Trammell SA, Perlman S, Cohen MS, Fehr AR, Brenner C. Coronavirus Infection and PARP Expression Dysregulate the NAD Metabolome: A Potentially Actionable Component of Innate Immunity. bioRxiv. 2020. https://doi.org/10.1101/2020.04.17.047480

79. Traba J, Kwarteng-Siaw M, Okoli TC, Li J, Huffstutler RD, Bray A, Waclawiw MA, Han K, Pelletier M, Sauve AA, Siegel RM, Sack MN. Fasting and refeeding differentially regulate NLRP3 inflammasome activation in human subjects. J Clin Invest. 2015; 125:4592-600. https://doi.org/10.1172/JCl83260 PMID:26529255

80. Elhassan YS, Kluckova K, Fletcher RS, Schmidt MS, Garten A, Doig CL, Cartwright DM, Oakey L, Burley CV, Jenkinson N, Wilson M, Lucas SJ, Akerman I, et al.
Nicotinamide riboside augments the aged human skeletal muscle $\mathrm{NAD}^{+}$metabolome and induces transcriptomic and anti-inflammatory signatures. Cell Rep. 2019; 28:1717-1728.e6.

https://doi.org/10.1016/j.celrep.2019.07.043

PMID:31412242

81. Siu KL, Yuen KS, Castaño-Rodriguez C, Ye ZW, Yeung ML, Fung SY, Yuan S, Chan CP, Yuen KY, Enjuanes L, Jin DY. Severe acute respiratory syndrome coronavirus ORF3a protein activates the NLRP3 inflammasome by promoting TRAF3-dependent ubiquitination of ASC. FASEB J. 2019; 33:8865-77.

https://doi.org/10.1096/fj.201802418R

PMID: $\underline{31034780}$

82. Shi CS, Nabar NR, Huang NN, Kehrl JH. SARScoronavirus open reading frame- $8 \mathrm{~b}$ triggers intracellular stress pathways and activates NLRP3 inflammasomes. Cell Death Discov. 2019; 5:101.

https://doi.org/10.1038/s41420-019-0181-7 PMID:31231549

83. Youm YH, Grant RW, McCabe LR, Albarado DC, Nguyen KY, Ravussin A, Pistell P, Newman S, Carter R, Laque A, Münzberg $\mathrm{H}$, Rosen $\mathrm{CJ}$, Ingram DK, et al. Canonical Nlrp3 inflammasome links systemic low-grade inflammation to functional decline in aging. Cell Metab. 2013; 18:519-32.

https://doi.org/10.1016/j.cmet.2013.09.010 PMID:24093676

84. Furman D, Chang J, Lartigue L, Bolen CR, Haddad F, Gaudilliere B, Ganio EA, Fragiadakis GK, Spitzer MH, Douchet I, Daburon S, Moreau JF, Nolan GP, et al. Expression of specific inflammasome gene modules stratifies older individuals into two extreme clinical and immunological states. Nat Med. 2017; 23:174-84.

https://doi.org/10.1038/nm.4267 PMID:28092664

85. Stefan N, Birkenfeld AL, Schulze MB, Ludwig DS. Obesity and impaired metabolic health in patients with COVID-19. Nat Rev Endocrinol. 2020:1-2. [Epub ahead of print].

https://doi.org/10.1038/s41574-020-0364-6 PMID: $\underline{32327737}$

86. Park HL, Shim SH, Lee EY, Cho W, Park S, Jeon HJ, Ahn SY, Kim H, Nam JH. Obesity-induced chronic inflammation is associated with the reduced efficacy of influenza vaccine. Hum Vaccin Immunother. 2014; 10:1181-86.

https://doi.org/10.4161/hv.28332

PMID:24614530

87. Kulcsar KA, Coleman CM, Beck SE, Frieman MB. Comorbid diabetes results in immune dysregulation and enhanced disease severity following MERS-CoV infection. JCl Insight. 2019; 4:e131774. 
https://doi.org/10.1172/jci.insight.131774 PMID:31550243

88. Guan WJ, Liang WH, Zhao Y, Liang HR, Chen ZS, Li YM, Liu XQ, Chen RC, Tang CL, Wang T, Ou CQ, Li L, Chen PY, et al, and China Medical Treatment Expert Group for COVID-19. Comorbidity and its impact on 1590 patients with COVID-19 in China: a nationwide analysis. Eur Respir J. 2020; 55:2000547. https://doi.org/10.1183/13993003.00547-2020 PMID:32217650

89. Ferrucci L, Fabbri E. Inflammageing: chronic inflammation in ageing, cardiovascular disease, and frailty. Nat Rev Cardiol. 2018; 15:505-22.

https://doi.org/10.1038/s41569-018-0064-2 PMID:30065258

90. Oberdoerffer P, Michan S, McVay M, Mostoslavsky R, Vann J, Park SK, Hartlerode A, Stegmuller J, Hafner A, Loerch P, Wright SM, Mills KD, Bonni A, et al. SIRT1 redistribution on chromatin promotes genomic stability but alters gene expression during aging. Cell. 2008; 135:907-18.

https://doi.org/10.1016/i.cell.2008.10.025

PMID:19041753

91. Burgess RC, Misteli T, Oberdoerffer P. DNA damage, chromatin, and transcription: the trinity of aging. Curr Opin Cell Biol. 2012; 24:724-30.

https://doi.org/10.1016/i.ceb.2012.07.005

PMID:22902297

92. Gorbunova V, Seluanov A. DNA double strand break repair, aging and the chromatin connection. Mutat Res. 2016; 788:2-6.

https://doi.org/10.1016/j.mrfmmm.2016.02.004 PMID:26923716

93. Kugel S, Mostoslavsky R. Chromatin and beyond: the multitasking roles for SIRT6. Trends Biochem Sci. 2014; 39:72-81.

https://doi.org/10.1016/j.tibs.2013.12.002

PMID:24438746

94. Dobbin MM, Madabhushi R, Pan L, Chen Y, Kim D, Gao J, Ahanonu B, Pao PC, Qiu Y, Zhao Y, Tsai LH. SIRT1 collaborates with ATM and HDAC1 to maintain genomic stability in neurons. Nat Neurosci. 2013; 16:1008-15.

https://doi.org/10.1038/nn.3460 PMID:23852118

95. Horvath S. DNA methylation age of human tissues and cell types. Genome Biol. 2013; 14:R115.

https://doi.org/10.1186/gb-2013-14-10-r115

PMID:24138928

96. Fahy GM, Brooke RT, Watson JP, Good Z, Vasanawala SS, Maecker H, Leipold MD, Lin DT, Kobor MS, Horvath $\mathrm{S}$. Reversal of epigenetic aging and immunosenescent trends in humans. Aging Cell. 2019; 18:e13028. https://doi.org/10.1111/acel.13028

PMID:31496122

97. Keenan CR, Allan RS. Epigenomic drivers of immune dysfunction in aging. Aging Cell. 2019; 18:e12878.

https://doi.org/10.1111/acel.12878

PMID:30488545

98. Avgousti DC, Herrmann C, Kulej K, Pancholi NJ, Sekulic N, Petrescu J, Molden RC, Blumenthal D, Paris AJ, Reyes ED, Ostapchuk P, Hearing P, Seeholzer SH, et al. A core viral protein binds host nucleosomes to sequester immune danger signals. Nature. 2016; 535:173-77.

https://doi.org/10.1038/nature18317

PMID:27362237

99. Schäfer A, Baric RS. Epigenetic landscape during coronavirus infection. Pathogens. 2017; 6:8. https://doi.org/10.3390/pathogens6010008 PMID:28212305

100. Foster SL, Hargreaves DC, Medzhitov R. Gene-specific control of inflammation by TLR-induced chromatin modifications. Nature. 2007; 447:972-78.

https://doi.org/10.1038/nature05836

PMID:17538624

101. Murayama A, Sakura K, Nakama M, Yasuzawa-Tanaka K, Fujita E, Tateishi Y, Wang Y, Ushijima T, Baba T, Shibuya K, Shibuya A, Kawabe Y, Yanagisawa J. A specific CpG site demethylation in the human interleukin 2 gene promoter is an epigenetic memory. EMBO J. 2006; 25:1081-92.

https://doi.org/10.1038/sj.emboj.7601012

PMID:16498406

102. Menachery VD, Schäfer A, Burnum-Johnson KE, Mitchell HD, Eisfeld AJ, Walters KB, Nicora CD, Purvine SO, Casey CP, Monroe ME, Weitz KK, Stratton KG, Webb-Robertson BM, et al. MERS-CoV and H5N1 influenza virus antagonize antigen presentation by altering the epigenetic landscape. Proc Natl Acad Sci USA. 2018; 115:E1012-21.

https://doi.org/10.1073/pnas.1706928115

PMID:29339515

103. Menachery VD, Eisfeld AJ, Schäfer A, Josset L, Sims AC, Proll S, Fan S, Li C, Neumann G, Tilton SC, Chang J, Gralinski LE, Long $C$, et al. Pathogenic influenza viruses and coronaviruses utilize similar and contrasting approaches to control interferon-stimulated gene responses. mBio. 2014; 5:e01174-14.

https://doi.org/10.1128/mBio.01174-14

PMID:24846384

104. Hoffmann M, Kleine-Weber $\mathrm{H}$, Schroeder S, Krüger $\mathrm{N}$, Herrler T, Erichsen S, Schiergens TS, Herrler G, Wu NH, Nitsche A, Müller MA, Drosten C, Pöhlmann S. SARSCoV-2 cell entry depends on ACE2 and TMPRSS2 and 
is blocked by a clinically proven protease inhibitor. Cell. 2020; 181:271-280.e8.

https://doi.org/10.1016/j.cell.2020.02.052 PMID:32142651

105. Cao Y, Li L, Feng Z, Wan S, Huang P, Sun X, Wen F, Huang $X$, Ning G, Wang W. Comparative genetic analysis of the novel coronavirus (2019-nCoV/SARSCoV-2) receptor ACE2 in different populations. Cell Discov. 2020; 6:11. https://doi.org/10.1038/s41421-020-0147-1 PMID:32133153

106. Hamming I, Timens W, Bulthuis ML, Lely AT, Navis G, van Goor $\mathrm{H}$. Tissue distribution of ACE2 protein, the functional receptor for SARS coronavirus. A first step in understanding SARS pathogenesis. J Pathol. 2004; 203:631-37.

https://doi.org/10.1002/path.1570

PMID:15141377

107. Patel VB, Zhong JC, Grant MB, Oudit GY. Role of the ACE2/angiotensin 1-7 axis of the renin-angiotensin system in heart failure. Circ Res. 2016; 118:1313-26. https://doi.org/10.1161/CIRCRESAHA.116.307708 PMID:27081112

108. Xie X, Chen J, Wang X, Zhang F, Liu Y. Age- and gender-related difference of ACE2 expression in rat lung. Life Sci. 2006; 78:2166-71.

https://doi.org/10.1016/j.Ifs.2005.09.038 PMID:16303146

109. Yoon HE, Kim EN, Kim MY, Lim JH, Jang IA, Ban TH, Shin SJ, Park CW, Chang YS, Choi BS. Age-associated changes in the vascular renin-angiotensin system in mice. Oxid Med Cell Longev. 2016; 2016:6731093. https://doi.org/10.1155/2016/6731093 PMID:27200147

110. Smith JC, Sausville EL, Girish V, Yuan ML, John KM, Sheltzer JM. Cigarette smoke exposure and inflammatory signaling increase the expression of the SARS-CoV-2 receptor ACE2 in the respiratory tract. bioRxiv. 2020.

https://doi.org/10.1101/2020.03.28.013672

111. Pinto BG, Oliveira AE, Singh $Y$, Jimenez $L$, Goncalves AN, Ogava RL, Creighton R, Peron JP, Nakaya HI. ACE2 Expression is Increased in the Lungs of Patients with Comorbidities Associated with Severe COVID-19. medRxiv. 2020.

https://doi.org/10.1101/2020.03.21.20040261

112. Sawalha AH, Zhao M, Coit P, Lu Q. Epigenetic dysregulation of ACE2 and interferon-regulated genes might suggest increased COVID-19 susceptibility and severity in lupus patients. Clin Immunol. 2020; 215:108410.

https://doi.org/10.1016/j.clim.2020.108410
PMID: $\underline{32276140}$

113. Corley MJ, Ndhlovu LC. DNA Methylation Analysis of the COVID-19 Host Cell Receptor, Angiotensin I Converting Enzyme 2 Gene (ACE2) in the Respiratory System Reveal Age and Gender Differences. Preprints. 2020.

https://doi.org/10.20944/preprints202003.0295.v1

114. Imai Y, Kuba K, Rao S, Huan Y, Guo F, Guan B, Yang P, Sarao R, Wada T, Leong-Poi $H$, Crackower MA, Fukamizu A, Hui CC, et al. Angiotensin-converting enzyme 2 protects from severe acute lung failure. Nature. 2005; 436:112-16.

https://doi.org/10.1038/nature03712

PMID:16001071

115. Kuba K, Imai Y, Rao S, Gao H, Guo F, Guan B, Huan Y, Yang $P$, Zhang Y, Deng W, Bao L, Zhang B, Liu G, et al. A crucial role of angiotensin converting enzyme 2 (ACE2) in SARS coronavirus-induced lung injury. Nat Med. 2005; 11:875-79.

https://doi.org/10.1038/nm1267

PMID: 16007097

116. Dhawale VS, Amara VR, Karpe PA, Malek V, Patel D, Tikoo K. Activation of angiotensin-converting enzyme 2 (ACE2) attenuates allergic airway inflammation in rat asthma model. Toxicol Appl Pharmacol. 2016; 306:17-26.

https://doi.org/10.1016/i.taap.2016.06.026 PMID:27343405

117. Fan $X$, Wang $Y$, Sun $K$, Zhang $W$, Yang $X$, Wang $S$, Zhen Y, Wang J, Li W, Han Y, Liu T, Wang X, Chen J, et al, and Study Group for Pharmacogenomic Based Antihypertensive Drugs Selection, Effects and Side Effects, in Rural Area Chinese. Polymorphisms of ACE2 gene are associated with essential hypertension and antihypertensive effects of captopril in women. Clin Pharmacol Ther. 2007; 82:187-96. https://doi.org/10.1038/sj.clpt.6100214 PMID: 17473847

118. Sano S, Oshima K, Wang Y, Katanasaka Y, Sano M, Walsh K. CRISPR-mediated gene editing to assess the roles of Tet2 and Dnmt3a in clonal hematopoiesis and cardiovascular disease. Circ Res. 2018; 123:335-41. https://doi.org/10.1161/CIRCRESAHA.118.313225 PMID:29728415

119. Danser AH, Epstein M, Batlle D. Renin-angiotensin system blockers and the COVID-19 pandemic: at present there is no evidence to abandon reninangiotensin system blockers. Hypertension. 2020; 75:1382-85.

https://doi.org/10.1161/HYPERTENSIONAHA.120.1 5082 PMID:32208987

120. Vaduganathan M, Vardeny O, Michel T, McMurray JJ, 
Pfeffer MA, Solomon SD. Renin-angiotensinaldosterone system inhibitors in patients with covid19. N Engl J Med. 2020; 382:1653-59.

https://doi.org/10.1056/NEJMsr2005760

PMID:32227760

121. Ferrario CM, Jessup J, Chappell MC, Averill DB, Brosnihan KB, Tallant EA, Diz DI, Gallagher PE. Effect of angiotensin-converting enzyme inhibition and angiotensin II receptor blockers on cardiac angiotensin-converting enzyme 2. Circulation. 2005; 111:2605-10.

https://doi.org/10.1161/CIRCULATIONAHA.104.510461 PMID:15897343

122. Monteil V, Kwon $H$, Prado $P$, Hagelkrüys A, Wimmer RA, Stahl M, Leopoldi A, Garreta E, Hurtado Del Pozo C, Prosper F, Romero JP, Wirnsberger G, Zhang H, et al. Inhibition of SARS-CoV-2 infections in engineered human tissues using clinical-grade soluble human ACE2. Cell. 2020; 181:905-913.e7.

https://doi.org/10.1016/j.cell.2020.04.004 PMID:32333836

123. Kwon HS, Brent MM, Getachew R, Jayakumar $\mathrm{P}$, Chen LF, Schnolzer M, McBurney MW, Marmorstein R, Greene WC, Ott M. Human immunodeficiency virus type 1 tat protein inhibits the SIRT1 deacetylase and induces $\mathrm{T}$ cell hyperactivation. Cell Host Microbe. 2008; 3:158-67.

https://doi.org/10.1016/j.chom.2008.02.002

PMID:18329615

124. Clarke NE, Belyaev ND, Lambert DW, Turner AJ. Epigenetic regulation of angiotensin-converting enzyme 2 (ACE2) by SIRT1 under conditions of cell energy stress. Clin Sci (Lond). 2014; 126:507-16.

https://doi.org/10.1042/CS20130291

PMID:24147777

125. Chini EN, Chini CC, Espindola Netto JM, de Oliveira GC, van Schooten $\mathrm{W}$. The pharmacology of CD38/NADase: an emerging target in cancer and diseases of aging. Trends Pharmacol Sci. 2018; 39:424-36. https://doi.org/10.1016/j.tips.2018.02.001 PMID:29482842

126. Gupte R, Liu Z, Kraus WL. PARPs and ADP-ribosylation: recent advances linking molecular functions to biological outcomes. Genes Dev. 2017; 31:101-26.

https://doi.org/10.1101/gad.291518.116

PMID:28202539

127. Grunewald ME, Chen Y, Kuny C, Maejima T, Lease R, Ferraris D, Aikawa M, Sullivan CS, Perlman S, Fehr AR. The coronavirus macrodomain is required to prevent PARP-mediated inhibition of virus replication and enhancement of IFN expression. PLoS Pathog. 2019; 15:e1007756. https://doi.org/10.1371/journal.ppat.1007756 PMID:31095648

128. Gao R, Ma Z, Hu Y, Chen J, Shetty S, Fu J. Sirt1 restrains lung inflammasome activation in a murine model of sepsis. Am J Physiol Lung Cell Mol Physiol. 2015; 308:L847-53.

https://doi.org/10.1152/ajplung.00274.2014

PMID:25659903

129. Kumar V, Agrawal R, Pandey A, Kopf S, Hoeffgen M, Kaymak S, Bandapalli OR, Gorbunova V, Seluanov A, Mall MA, Herzig S, Nawroth PP. Compromised DNA repair is responsible for diabetes-associated fibrosis. EMBO J. 2020:e103477. [Epub ahead of print]. https://doi.org/10.15252/embj.2019103477 PMID:32338774

130. Chen GD, Yu WD, Chen XP. SirT1 activator represses the transcription of TNF- $\alpha$ in THP-1 cells of a sepsis model via deacetylation of H4K16. Mol Med Rep. 2016; 14:5544-50.

https://doi.org/10.3892/mmr.2016.5942

PMID:27878240

131. Kawahara TL, Michishita E, Adler AS, Damian M, Berber E, Lin M, McCord RA, Ongaigui KC, Boxer LD, Chang HY, Chua KF. SIRT6 links histone H3 lysine 9 deacetylation to NF-kappaB-dependent gene expression and organismal life span. Cell. 2009; 136:62-74.

https://doi.org/10.1016/i.cell.2008.10.052 PMID: 19135889

132. Tian X, Firsanov D, Zhang Z, Cheng Y, Luo L, Tombline G, Tan R, Simon M, Henderson S, Steffan J, Goldfarb A, Tam J, Zheng K, et al. SIRT6 is responsible for more efficient DNA double-strand break repair in long-lived species. Cell. 2019; 177:622-638.e22. https://doi.org/10.1016/j.cell.2019.03.043 PMID:31002797

133. Bonkowski MS, Sinclair DA. Slowing ageing by design: the rise of $\mathrm{NAD}^{+}$and sirtuin-activating compounds. Nat Rev Mol Cell Biol. 2016; 17:679-90. https://doi.org/10.1038/nrm.2016.93 PMID:27552971

134. Levine $M E$, Lu AT, Quach $A$, Chen BH, Assimes $T L$, Bandinelli S, Hou L, Baccarelli AA, Stewart JD, Li Y, Whitsel EA, Wilson JG, Reiner AP, et al. An epigenetic biomarker of aging for lifespan and healthspan. Aging (Albany NY). 2018; 10:573-91.

https://doi.org/10.18632/aging.101414 PMID:29676998

135. Lu AT, Quach A, Wilson JG, Reiner AP, Aviv A, Raj K, Hou L, Baccarelli AA, Li Y, Stewart JD, Whitsel EA, Assimes TL, Ferrucci L, Horvath S. DNA methylation GrimAge strongly predicts lifespan and healthspan. Aging (Albany NY). 2019; 11:303-27. 
https://doi.org/10.18632/aging.101684 PMID:30669119

136. Zhang $Y$, Wilson R, Heiss J, Breitling LP, Saum KU, Schöttker B, Holleczek B, Waldenberger M, Peters A, Brenner $\mathrm{H}$. DNA methylation signatures in peripheral blood strongly predict all-cause mortality. Nat Commun. 2017; 8:14617.

https://doi.org/10.1038/ncomms14617 PMID:28303888

137. Alpert A, Pickman $Y$, Leipold $M$, Rosenberg-Hasson $Y$, Ji X, Gaujoux R, Rabani H, Starosvetsky E, Kveler K, Schaffert S, Furman D, Caspi O, Rosenschein U, et al. A clinically meaningful metric of immune age derived from high-dimensional longitudinal monitoring. Nat Med. 2019; 25:487-95.

https://doi.org/10.1038/s41591-019-0381-y PMID: $\underline{30842675}$

138. Mamoshina P, Volosnikova M, Ozerov IV, Putin E, Skibina E, Cortese F, Zhavoronkov A. Machine learning on human muscle transcriptomic data for biomarker discovery and tissue-specific drug target identification. Front Genet. 2018; 9:242.

https://doi.org/10.3389/fgene.2018.00242 PMID: $\underline{30050560}$

139. Rockwood K, Mitnitski A. Frailty defined by deficit accumulation and geriatric medicine defined by frailty. Clin Geriatr Med. 2011; 27:17-26.

https://doi.org/10.1016/j.cger.2010.08.008 PMID:21093719

140. Fried LP, Tangen CM, Walston J, Newman AB, Hirsch C, Gottdiener J, Seeman T, Tracy R, Kop WJ, Burke G, McBurnie MA, and Cardiovascular Health Study Collaborative Research Group. Frailty in older adults: evidence for a phenotype. J Gerontol A Biol Sci Med Sci. 2001; 56:M146-56.

https://doi.org/10.1093/gerona/56.3.m146 PMID:11253156

141. Lehallier B, Gate D, Schaum N, Nanasi T, Lee SE, Yousef $H$, Moran Losada P, Berdnik D, Keller A, Verghese J, Sathyan S, Franceschi C, Milman S, et al. Undulating changes in human plasma proteome profiles across the lifespan. Nat Med. 2019; 25:1843-50.

https://doi.org/10.1038/s41591-019-0673-2 PMID:31806903

142. Vilaj M, Gudelj I, Trbojević-Akmačić I, Lauc G, Pezer M. IgG Glycans as a Biomarker of Biological Age. In: Moskalev A, ed. Biomarkers of Human Aging. Cham: Springer International Publishing, 2019. pp. 81-99. https://doi.org/10.1007/978-3-030-24970-0 7

143. Gudelj I, Keser T, Vučković F, Škaro V, Goreta SŠ, Pavić T, Dumić J, Primorac D, Lauc G, Gornik O. Estimation of human age using n-glycan profiles from bloodstains. Int J Legal Med. 2015; 129:955-61. https://doi.org/10.1007/s00414-015-1162-x PMID:25787342

144. Krištić J, Vučković F, Menni C, Klarić L, Keser T, Beceheli I, Pučić-Baković M, Novokmet M, Mangino M, Thaqi K, Rudan P, Novokmet N, Sarac J, et al. Glycans are a novel biomarker of chronological and biological ages. J Gerontol A Biol Sci Med Sci. 2014; 69:779-89.

https://doi.org/10.1093/gerona/glt190

PMID:24325898

145. Williams FM, Freydin $M$, Mangino $M$, Couvreur $S$, Visconti A, Bowyer RC, Le Roy Cl, Falchi M, Sudre C, Davies R, Hammond C, Menni C, Steves C, et al. Selfreported symptoms of covid-19 including symptoms most predictive of SARS-CoV-2 infection, are heritable. medRxiv. 2020.

https://doi.org/10.1101/2020.04.22.20072124

146. Brodin P, Jojic V, Gao T, Bhattacharya S, Angel CJ, Furman D, Shen-Orr S, Dekker CL, Swan GE, Butte AJ, Maecker HT, Davis MM. Variation in the human immune system is largely driven by non-heritable influences. Cell. 2015; 160:37-47.

https://doi.org/10.1016/j.cell.2014.12.020

PMID:25594173

147. Jin Z, Liu Y. DNA methylation in human diseases. Genes Dis. 2018; 5:1-8. https://doi.org/10.1016/j.gendis.2018.01.002 PMID: $\underline{30258928}$

148. Lauc G, Sinclair D. Biomarkers of biological age as predictors of COVID-19 disease severity. Aging (Albany NY). 2020; 12:6490-91. https://doi.org/10.18632/aging.103052 PMID: $\underline{32268300}$

149. Yu X, Wang Y, Kristic J, Dong J, Chu X, Ge S, Wang H, Fang $\mathrm{H}$, Gao Q, Liu D, Zhao Z, Peng H, Pucic Bakovic M, et al. Profiling IgG $n$-glycans as potential biomarker of chronological and biological ages: a community-based study in a han chinese population. Medicine (Baltimore). 2016; 95:e4112. https://doi.org/10.1097/MD.0000000000004112 PMID:27428197

150. Russell AC, Kepka A, Trbojević-Akmačić I, Ugrina I, Song $M$, Hui J, Hunter M, Laws SM, Lauc G, Wang W. Increased central adiposity is associated with proinflammatory immunoglobulin $G$ n-glycans. Immunobiology. 2019; 224:110-15. https://doi.org/10.1016/j.imbio.2018.10.002 PMID: $\underline{30446335}$

151. Karsten CM, Pandey MK, Figge J, Kilchenstein R, Taylor PR, Rosas M, McDonald JU, Orr SJ, Berger M, Petzold 
D, Blanchard V, Winkler A, Hess C, et al. Antiinflammatory activity of IgG1 mediated by $\mathrm{fc}$ galactosylation and association of FcyRIIB and dectin1. Nat Med. 2012; 18:1401-06.

https://doi.org/10.1038/nm.2862

PMID:22922409

152. Lemmers RF, Vilaj $M$, Urda $D$, Agakov $F$, Šimurina $M$, Klaric L, Rudan I, Campbell H, Hayward C, Wilson JF, Lieverse AG, Gornik O, Sijbrands EJ, et al. IgG glycan patterns are associated with type 2 diabetes in independent european populations. Biochim Biophys Acta Gen Subj. 2017; 1861:2240-49.

https://doi.org/10.1016/j.bbagen.2017.06.020 PMID:28668296

153. Clarke RE, Dordevic AL, Tan SM, Ryan L, Coughlan MT. Dietary advanced glycation end products and risk factors for chronic disease: a systematic review of randomised controlled trials. Nutrients. 2016; 8:125. https://doi.org/10.3390/nu8030125 PMID:26938557

154. Singh R, Barden A, Mori T, Beilin L. Advanced glycation end-products: a review. Diabetologia. 2001; 44:129-46.

https://doi.org/10.1007/s001250051591 PMID:11270668

155. Son S, Hwang I, Han SH, Shin JS, Shin OS, Yu JW. Advanced glycation end products impair NLRP3 inflammasome-mediated innate immune responses in macrophages. J Biol Chem. 2017; 292:20437-48. https://doi.org/10.1074/jbc.M117.806307 PMID:29051224

156. Chen IY, Moriyama M, Chang MF, Ichinohe T. Severe acute respiratory syndrome coronavirus viroporin 3a activates the NLRP3 inflammasome. Front Microbiol. 2019; 10:50.

https://doi.org/10.3389/fmicb.2019.00050

PMID:30761102

157. Walls AC, Park YJ, Tortorici MA, Wall A, McGuire AT, Veesler D. Structure, function, and antigenicity of the SARS-CoV-2 spike glycoprotein. Cell. 2020; 181:281-292.e6. https://doi.org/10.1016/j.cell.2020.02.058 PMID:32155444

158. Nicholls JM, Bourne AJ, Chen H, Guan Y, Peiris JS. Sialic acid receptor detection in the human respiratory tract: evidence for widespread distribution of potential binding sites for human and avian influenza viruses. Respir Res. 2007; 8:73.

https://doi.org/10.1186/1465-9921-8-73

PMID:17961210

159. Sharma S, Ray A, Sadasivam B. Metformin in COVID19: a possible role beyond diabetes. Diabetes Res Clin Pract. 2020; 164:108183. https://doi.org/10.1016/j.diabres.2020.108183 PMID:32360697

160. Weichhart $T$, Hengstschläger $M$, Linke $M$. Regulation of innate immune cell function by mTOR. Nat Rev Immunol. 2015; 15:599-614. https://doi.org/10.1038/nri3901 PMID:26403194

161. Powell JD, Pollizzi KN, Heikamp EB, Horton MR. Regulation of immune responses by mTOR. Annu Rev Immunol. 2012; 30:39-68. https://doi.org/10.1146/annurev-immunol-020711075024 PMID:22136167

162. Mannick JB, Del Giudice G, Lattanzi M, Valiante NM, Praestgaard J, Huang B, Lonetto MA, Maecker HT, Kovarik J, Carson S, Glass DJ, Klickstein LB. mTOR inhibition improves immune function in the elderly. Sci Transl Med. 2014; 6:268ra179.

https://doi.org/10.1126/scitranslmed.3009892 PMID:25540326

163. Mannick JB, Morris M, Hockey HP, Roma G, Beibel M, Kulmatycki K, Watkins M, Shavlakadze T, Zhou W, Quinn D, Glass DJ, Klickstein LB. TORC1 inhibition enhances immune function and reduces infections in the elderly. Sci Transl Med. 2018; 10:eaaq1564. https://doi.org/10.1126/scitranslmed.aaq1564 PMID:29997249

164. Chen Y, Gu F, Guan JL. Metformin might inhibit virus through increasing insulin sensitivity. Chin Med J (Engl). 2018; 131:376-77. https://doi.org/10.4103/0366-6999.223856 PMID:29363663

165. Kulkarni AS, Gubbi S, Barzilai N. Benefits of Metformin in Attenuating the Hallmarks of Aging. Cell Metab. 2020. [Epub ahead of print].

https://doi.org/10.1016/j.cmet.2020.04.001 PMID:32333835

166. Barzilai N, Crandall JP, Kritchevsky SB, Espeland MA. Metformin as a tool to target aging. Cell Metab. 2016; 23:1060-65.

https://doi.org/10.1016/j.cmet.2016.05.011 PMID:27304507

167. Goodwin K, Viboud C, Simonsen L. Antibody response to influenza vaccination in the elderly: a quantitative review. Vaccine. 2006; 24:1159-69. https://doi.org/10.1016/i.vaccine.2005.08.105 PMID:16213065

168. Leggat DJ, Thompson RS, Khaskhely NM, lyer AS, Westerink MA. The immune response to pneumococcal polysaccharides 14 and 23F among elderly individuals consists predominantly of switched memory B cells. J Infect Dis. 2013; 208:101-08. https://doi.org/10.1093/infdis/jit139 PMID:23547142 
169. Frasca D, Blomberg BB. Inflammaging decreases adaptive and innate immune responses in mice and humans. Biogerontology. 2016; 17:7-19. https://doi.org/10.1007/s10522-015-9578-8 PMID:25921609

170. Chiumello D, Coppola S, Froio S, Gotti M. What's next after ARDS: long-term outcomes. Respir Care. 2016; 61:689-99. https://doi.org/10.4187/respcare.04644 PMID:27121623

171. Ocampo A, Reddy P, Martinez-Redondo P, PlateroLuengo A, Hatanaka F, Hishida T, Li M, Lam D, Kurita M, Beyret E, Araoka T, Vazquez-Ferrer E, Donoso D, et al. In vivo amelioration of age-associated hallmarks by partial reprogramming. Cell. 2016; 167:17191733.e12.

https://doi.org/10.1016/i.cell.2016.11.052 PMID:27984723

172. Lu Y, Krishnan A, Brommer B, Tian X, Meer M, Vera DL, Wang C, Zeng Q, Yu D, Bonkowski MS, Yang JH, Hoffmann EM, Zhou S, et al. Reversal of ageing- and injury-induced vision loss by Tet-dependent epigenetic reprogramming. bioRxiv. 2019.

173. Sarkar TJ, Quarta M, Mukherjee S, Colville A, Paine $P$, Doan L, Tran CM, Chu CR, Horvath S, Qi LS, Bhutani N, Rando TA, Sebastiano V. Transient non-integrative expression of nuclear reprogramming factors promotes multifaceted amelioration of aging in human cells. Nat Commun. 2020; 11:1545.

https://doi.org/10.1038/s41467-020-15174-3 PMID:32210226

174. Horvath S, Singh K, Raj K, Khairnar S, Sanghavi A, Shrivastava A, Zoller JA, Li CZ, Herenu CB, CanatelliMallat M, Lehmann M, Solberg Woods LC, Martinez $A G$, et al. Reversing age: dual species measurement of epigenetic age with a single clock. bioRxiv. 2020. https://doi.org/10.1101/2020.05.07.082917

175. Petrilli CM, Jones SA, Yang J, Rajagopalan H, O'Donnell LF, Chernyak Y, Tobin K, Cerfolio RJ, Francois F, Horwitz LI. Factors associated with hospitalization and critical illness among 4,103 patients with COVID-19 disease in New York City. medRxiv. 2020. https://doi.org/10.1101/2020.04.08.20057794

176. Matsuyama R, Nishiura H, Kutsuna S, Hayakawa K, Ohmagari N. Clinical determinants of the severity of middle east respiratory syndrome (MERS): a systematic review and meta-analysis. BMC Public Health. 2016; 16:1203.

https://doi.org/10.1186/s12889-016-3881-4 PMID:27899100

177. Rivers CM, Majumder MS, Lofgren ET. Risks of death and severe disease in patients with middle east respiratory syndrome coronavirus, 2012-2015. Am J Epidemiol. 2016; 184:460-64.

https://doi.org/10.1093/aje/kww013

PMID:27608662

178. Yang YM, Hsu CY, Lai CC, Yen MF, Wikramaratna PS, Chen $\mathrm{HH}$, Wang $\mathrm{TH}$. Impact of comorbidity on fatality rate of patients with middle east respiratory syndrome. Sci Rep. 2017; 7:11307.

https://doi.org/10.1038/s41598-017-10402-1 PMID:28900101

179. Moni MA, Liò P. Network-based analysis of comorbidities risk during an infection: SARS and HIV case studies. BMC Bioinformatics. 2014; 15:333. https://doi.org/10.1186/1471-2105-15-333 PMID:25344230

180. Zhou F, Yu T, Du R, Fan G, Liu Y, Liu Z, Xiang J, Wang Y, Song B, Gu X, Guan L, Wei Y, Li H, et al. Clinical course and risk factors for mortality of adult inpatients with COVID-19 in wuhan, China: a retrospective cohort study. Lancet. 2020; 395:1054-62.

https://doi.org/10.1016/S0140-6736(20)30566-3 PMID:32171076

181. Mehra MR, Desai SS, Kuy S, Henry TD, Patel AN. Cardiovascular Disease, Drug Therapy, and Mortality in Covid-19. N Engl J Med. 2020. [Epub ahead of print].

https://doi.org/10.1056/NEJMoa2007621 PMID:32356626

182. Badawi A, Ryoo SG. Prevalence of comorbidities in the middle east respiratory syndrome coronavirus (MERS(oV): a systematic review and meta-analysis. Int J Infect Dis. 2016; 49:129-33.

https://doi.org/10.1016/j.ijid.2016.06.015 PMID:27352628

183. Richardson S, Hirsch JS, Narasimhan M, Crawford JM, McGinn T, Davidson KW, Barnaby DP, Becker LB, Chelico JD, Cohen SL, Cookingham J, Coppa K, Diefenbach MA, and the Northwell COVID-19 Research Consortium. Presenting Characteristics, Comorbidities, and Outcomes Among 5700 Patients Hospitalized With COVID-19 in the New York City Area. JAMA. 2020:e206775. [Epub ahead of print]. https://doi.org/10.1001/jama.2020.6775 PMID:32320003

184. Larson AS, Savastano L, Kadirvel R, Kallmes DF, Hassan AE, Brinjikji W. COVID-19 and the CerebroCardiovascular Systems: What do we know so Far? J Am Heart Assoc. 2020:e016793. [Epub ahead of print]. https://doi.org/10.1161/JAHA.120.016793 PMID:32393136

185. Yang JK, Feng Y, Yuan MY, Yuan SY, Fu HJ, Wu BY, Sun 
GZ, Yang GR, Zhang XL, Wang L, Xu X, Xu XP, Chan JC. Plasma glucose levels and diabetes are independent predictors for mortality and morbidity in patients with SARS. Diabet Med. 2006; 23:623-28.

https://doi.org/10.1111/j.1464-5491.2006.01861.x

PMID:16759303

186. Booth CM, Matukas LM, Tomlinson GA, Rachlis AR, Rose DB, Dwosh HA, Walmsley SL, Mazzulli T, Avendano M, Derkach P, Ephtimios IE, Kitai I, Mederski BD, et al. Clinical features and short-term outcomes of 144 patients with SARS in the greater toronto area. JAMA. 2003; 289:2801-09. https://doi.org/10.1001/jama.289.21.JOC30885 PMID: 12734147

187. Bhatraju PK, Ghassemieh BJ, Nichols $M$, Kim R, Jerome $K R$, Nalla AK, Greninger AL, Pipavath S, Wurfel MM, Evans L, Kritek PA, West TE, Luks A, et al. Covid-19 in Critically III Patients in the Seattle Region - Case Series. N Engl J Med. 2020; 382:2012-22. https://doi.org/10.1056/NEJMoa2004500 PMID:32227758

188. Zhu L, She ZG, Cheng X, Qin JJ, Zhang XJ, Cai J, Lei F, Wang $H$, Xie J, Wang W, Li H, Zhang P, Song X, et al. Association of Blood Glucose Control and Outcomes in Patients with COVID-19 and Pre-existing Type 2 Diabetes. Cell Metab. 2020. [Epub ahead of print]. https://doi.org/10.1016/i.cmet.2020.04.021 PMID:32369736
189. Frasca D, McElhaney J. Influence of obesity on pneumococcus infection risk in the elderly. Front Endocrinol (Lausanne). 2019; 10:71.

https://doi.org/10.3389/fendo.2019.00071

PMID:30814978

190. Cheng Y, Luo R, Wang K, Zhang M, Wang Z, Dong L, Li J, Yao Y, Ge S, Xu G. Kidney disease is associated with in-hospital death of patients with COVID-19. Kidney Int. 2020; 97:829-38. https://doi.org/10.1016/j.kint.2020.03.005 PMID:32247631

191. Wang JT, Sheng WH, Fang CT, Chen YC, Wang JL, Yu CJ, Chang SC, Yang PC. Clinical manifestations, laboratory findings, and treatment outcomes of SARS patients. Emerg Infect Dis. 2004; 10:818-24. https://doi.org/10.3201/eid1005.030640 PMID:15200814 